Denys Shatalov

\title{
NON-NIPPED MEMORY. THE HOLOCAUST IN THE SOVIET WAR MEMOIRS ${ }^{1}$
}

The article addresses the presentation of the mass murder of Jews during WWII in the Soviet printed production. An overall trend of ignoring the topic of the Holocaust in the Soviet media discourse is unquestioned. Yet, (non)presentation of the mass destruction of Jews in the Soviet literature, which is commonly emphasized by the researches, needs clarification. If we look at the Soviet literature on the Great Patriotic War (including fiction prose), we can trace a phenomenon described in this article through war memoirs. Alongside official ignoring of the Holocaust in the Soviet Union, the whole post-war period experienced mass publishing and re-publishing of memoir books which provided direct references to the murder of Jews by the Nazis during the war.

Herewith, combatants' memoirs would often touch very briefly on the murders of Jews, but give no explanations. Such reference style implies that the authors targeted the readers' background awareness. Detailed descriptions of Jewish discrimination, segregation, getthoisation and murder are found in the memoirs of former prisoners of war and partisans. The account of Nazi persecution of the Jews is an integral part of the stories of everyday life in the occupied territory, which often represents the major piece of the narrative. Under certain ideology, the mention of the murders of Jews was intentionally instrumentalized by the Soviet memoir writers seeking to demonstrate a criminal nature of Nazi collaborators.

As can be inferred from the Soviet war memoirs, we are not supposed to simplify a clear-cut attitude of ignoring and should conceptualize the phenomenon of «non-nipped memory» in semi-official narratives. Soviet narratives, particularly war memoirs, did not highlight Nazi persecution of the Jews as a separate phenomenon; although described in detail, it was seen only as a part of the «new order». In the Soviet setting, we do encounter ignoring of the Holocaust (as a separate phenomenon), but at the same time, although with certain limitations, the memory of the mass murder of the Soviet Jews was quite actively reflected in war memoirs.

Key words: memory of the Holocaust, war memoirs, mass killing, Soviet Jews, Nazi persecution.

\footnotetext{
The author expresses his deep gratitude to Viktoriia Serhiienko, Anna Medvedovska and Andrii
} Portnov, for recommendations, support and preliminary discussion of this text. 


\section{Nazi extermination of the Jews in the Soviet Public Discourse} (historiographic aspects)

The publications on the memory about the Holocaust in the Soviet Union usually touch upon two aspects - its complete ignoring and study of some rare cases when the story of the Nazi extermination of the Jews managed to penetrate public discourse: movies, fiction or stage productions. In my paper I try to demonstrate that our notions about the Holocaust presentation in the Soviet public discourse need correlations - because we can find out dozens explicit detailed mentions about Nazi extermination of the Jews in the Soviet time texts.

The main phases of the Holocaust commemoration/hushing up in the Soviet Union are covered in the papers of Anna Medvedovska, Ilya Altman and Kirill Feferman'. They demonstrate that the issue of Jews killing by Nazis appeared in the public discourse during the war as one of the elements of encouraging to fight fascism and as an «export product» - to get certain help from international Jewish organizations. Starting from the end of 1940s, the authorities «curtail» initiatives regarding commemoration of the mass killing sites ${ }^{3}$. The attempts to deliver some commemoration events in 1960s-1970s were half-dissident for their participants as well as for the authorities according to their opinion. To neutralize Jewish memory, the Soviet authorities started to present the sites of mass killings of Jews as sites where «Soviet civilians - victims of Fascists» were perished". At the same time, it was made possible that Jewish origin of the victims was mentioned on some memorials, first of all, in the province ${ }^{s}$

After the war some texts which cover Jew persecution by Nazis were published «by inertia», but, in general, according to Ilya Altman «starting from

${ }^{2}$ Kiril Feferman, Soviet Jewish Stepchild: The Holocaust in the Soviet Mindset, 1941-1964(Saarbrücken VDM Verlag, 2009), 96; Илья Альтман, «Мемориализация Холокоста в России: история, современность, перспективы», Неприкосновенный запас, № 2-3 (40-41) (2005), accessed December 17,

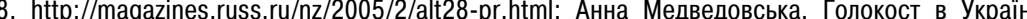
в суспільній думці кінця XX - початку XXI ст. (дис. ... канд. іст. наук, Дніпро, 2016), 52-95.

${ }^{3}$ Мордехай Альтшулер, «Деятельность евреев по увековечению памяти о Холокосте в Советском Союзе в эпоху Сталина», Яд Вашем: Исследования 1, (2009).

${ }^{4}$ Михаил Мицель, «Запрет на увековечение памяти как способ замалчивания Холокоста: практика КПУ в отношении Бабьего Яра», Голокост і сучасність: студії в Україні і світі, № 1 (2) (2007) 9-30; Victoria Khiterer, «Suppressed Memory: Memorialization of the Holocaust in Babi Yar (Kiev)», accessed December 19, 2018, http://aej.org.ua/history/1743.html; Jeff Mankoff, «Babi Yar and the Struggle for Memory», Ab Imperio, № 2 (2004): 393-415; William Korey, «A monument over in the Nazi-occupied Territories of the USSR, 1941-1945, ed. Lucjan Dobroszycki and Jeffery S. Gurock (Routledge, 1994), 61-74

${ }^{5}$ Альтман, «Мемориализация Холокоста в России». the end of 1940s till the beginning of 1960s, the Holocaust issue was not covered by the published literary works»' ${ }^{6}$. Such point of view is shared by the other authors who demonstrate the Soviet policy of hushing up the ethnicity of the Nazi terror victims in their works?. During the Khrushchev Thaw some texts were published intentionally focusing on the tragedy. From time to time they appeared also in $1970 \mathrm{~s}-1980 \mathrm{~s}^{8}$.

Traditionally, the majority of the authors who study Holocaust issue reflection in the Soviet literature concentrate their attention on the texts and publication circumstances of four texts - «Chernaya Kniga» («The Black Book») (edited by Ilya Ehrenburg) (1948), «Babi Yar» by Yevgeny Yevtushenko (1961), «Babi Yar» by Anatoly Kuznetsov (1968) and «Tyazhelyiy pesok» («Heavy Sand») by Anatoly Rybakov (1978). This canon is added by wartime poetry, as well as by Ilya Ehrenburg's «Burya» («Storm») (1946) and addressing to works of the Soviet Jewish writers in Yiddish". «Otche Nash» («Pater Noster») story (1946) and «Katakomby» («Catacombs») novel (1951) by Valentin Kataev, Leonid Pervomayskiy’s works - «Silnee Smerty» («Tougher than Death») poem and his verses «Majdanek», «V Babem Yare» («In Baby Yar») (1968), Naum Korzhavin’s collection of poems «Gody» («Years»), texts of Ilya Konstantinovskiy and some other works are recalled less often. I don't know papers specifically dedicated to the circumstances of unrestricted publications of the books in the Soviet Union

${ }^{6}$ Альтман, «Мемориализация Холокоста в России».

'Zvi Gitelman, «History, Memory and Politics. The Holocaust in the Soviet Union», Holocaustand Genocide Studies 5, no. 1 (1990): 23-37; Zvi Gitelman, «Politics and Historiography of the Holocaust in the Soviet Union», in Bitter Legacy: Confronting the Holocaust in the USSR, ed. Zvi Gitelman (Bloomington: Indiana University Press, 1997), 14-42; Zvi Gitelman, "Soviet Reactions on the Holocaust», in The Holocaust in the Soviet Union: Studies and Sources on the Destruction of the Jews in the Nazi-occupied Territories of the USSR, 1941-1945, ed. Lucjan Dobroszycki and Jeffery S. Gurock (Routledge, 1994), 3-27; see also Yitzhak Arad, "The Holocaust in Soviet Historiography», in The Historiography of the Holocaust Period. Proceedings of the Fifth Yad Vashem International Historical Conference, 1988, edited by Yisrael Period. Proceedings of the Fifth Yad Vashem International Historical Con

${ }^{8}$ Альтман, «Мемориализация Холокоста в России».

${ }^{9}$ Naya Lekht, Narratives of Return: Babii lar and Holocaust Literature in the Soviet Union (diss. for the degree Ph. D. of Slavic Languages and Literatures, University of California, 2013); Leona Toker, «The Holocaust in Russian Literature», in Literature of the Holocaust, ed. Alan Rosen (Campridge University Press, 2013), 118-130; Olga Baranova, «Politics of Memory of the Holocaust in the Soviet Union", accessed December 17, 2018, http://www.iwm.at/publications/5-junior-visiting-fellowsconferences/vol-xxxiv/politics-of-memory-of-the-holocaust-in-the-soviet-union/; Edith. W. Clowes,

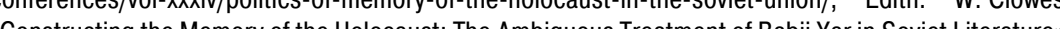
Constructing the Memory of the Holocaust. The Ambiguous Treatment of Babil Yar in Soviet Literatures, Partial Answers: Journal of Literature and the History of Ideas 3, no. 2 (2005): 153-182; Lukasz Hirszowicz, "The Holocaust in the Soviet mirror», in The Holocaust in the Soviet Union: Studies and Sources on the Destruction of the Jews in the Nazi-occupied Territories of the USSR, 1941-1945, ed. Lucjan Dobroszycki and Jeffery S. Gurock (Armonk, NY, 1993), 29-60. 
covering Holocaust issue in the West - Anne Frank's diary (1960) or reminiscences of Krystyna Żywulska (1960) and Mischket Liebermann (1979) ${ }^{10}$.

In the contemporary works the authors step away from the trend to describe situation with the Holocaust issue reflection in the Soviet society as an unambiguous hushing". The most accurate description of the situation with public presentation of Nazi genocide against Jews in the Soviet Union is given by Anna Medvedovska: «We cannot say that censorship completely restricted Holocaust issue to be touched upon. It was allowed to be covered in case the «correct context» was available and, of course, the scope had to be reasonable, the corners, such as collaboration, had to be cut»" ${ }^{12}$.

Thus, this way or the other, Holocaust issue was included into the war prose - among it traditionally mark out «Brestskaya krepost'» («The Brest Fortress») by Sergey Smirnov (1957), Boris Vasilyev’s stories «V spiskah ne znachilsya» («He was not on the Lists») (1974) and «A zori zdes tihie...» («The Dawns Here Are Quiet...») (1969), novel «Chernoe solntse» («The Black Sun») by Ivan Holovchenko and Aleksey Musienko (1969, republished), and Konstantin Simonov's wartime diaries (1975-1976 and 1982). Memoirs of Macha Rolnikas about Vilnius ghetto «I Must Tell» (1965) were republished few times ${ }^{13}$. However, today there are no papers focusing on the specific study of Holocaust issue reflection in fiction and feature materials covering the issue of «The Great Patriotic War».

In this article I would like to pay attention to Holocaust issue reflection in one of the components of such literature - the Soviet war memoirs. Immense annual runs of hundreds of war memoirs along with feature and documentary materials were very popular readings during the Soviet era. At least several copies one could find in any personal library. Dozens of these books included brief allusions to or detailed plots about persecution and killings of Jews. In the article I demonstrate the way how in Soviet war memoirs the Holocaust was described (or ignored) and what were the mainstream subjects, as well as what were allowed mentioning in such materials. At the same time it will provide us with an idea what were the sources of everyday knowledge about the Holocaust among the Soviet readers.

${ }^{10}$ Дневник Анны Франк, предисл. Ильи Эренбурга (Москва: Иностранная литература, 1960); Мишкет Либерман, Из берлинского гетто в новый мир (Москва: Прогресс, 1979); Кристина Живульская, Я пережила Освенцим (Москва: Издательство иностранной литературы, 1960).

11 James Loeffler, ««In Memory of Our Murdered (Jewish) Children»: Hearing the Holocaust in Soviet Jewish Culture», Slavic Review 73, no. 3 (2014): 587-611.

${ }^{12}$ Медведовська, Голокост в Україні в суспільній думці кінця XX - початку XXI ст., 63.

${ }^{13}$ Медведовська, Голокост в Україні в суспільній думці кінця XX - початку XXI ст., 63-65; Альтман, «Мемориализация Холокоста в России».
However, I should stress that the texts written in the Soviet time did not mention «Holocaust» (or «Shoah», «Final Solution») at all. Though the issue of Jews mass killing was mentioned in the works of the Soviet authors, a special terminology for its conceptualization was lacking. Knowing about the tragedy and featuring Jews as one of the categories of victims among civilians, the Soviet authors did not have words to define it. For example, Nazis' «actions» of perishing ghetto population were called «pogroms». Evidently, the Soviet memoirists faced the lack of suitable terminology and had to use the most matching, in their opinion, «old-fashioned» word, thought the pogroms of the tsarists' times and Nazi «actions» were absolutely different phenomena in both form and meaning ${ }^{14}$. I use the word «Holocaust» in the article when working with the Soviet texts, first of all, as a substitution for constructs like «killings of civilians of Jewish ethnicity» and etc., without adding any extra and minor meanings.

\section{Soviet War Memoirs as a Social Phenomenon}

The first edition of the memoirs covering the Second World War (or rather «the Great Patriotic War»") in the Soviet Union was published in $1944-1945^{16}$. At the end of 1940s the memoirs of the famous partisan leaders (Sidor Kovpak, Aleksey Fedorov, Pyotr Vershigora, Ivan Kozlov, Vasily Kozlov" and others) were published. Mass publications of the memoirs started in 1950s. In 1959 Military Publishing House of the Ministry of Defense of the USSR (Voenizdat) promoted a series of books «Voennyie memuaryi» («Military Memoirs»). Till 1991 several dozens of books were published yearly in this series. Another Voenizdat series, «Frontoviki rasskazyivayut» («War Veterans tell»), included mainly reminisces of soldiers and junior officers. Other «departmental» publishing houses that were heavily involved into memoirs publishing were Political Literature Publishing House of the Central Committee of the CPSU (Politizdat), Publishing House of the Army, Air Force and Navy Volunteer Society of the USSR

\footnotetext{
${ }^{14}$ I thank to Viktoriia Serhiienko for pointing out to this detail.

${ }^{15}$ The myth about «the Great Patriotic War» took key position in the Soviet Discourse, meaning GermanSoviet War that started on June 22, 1941. In fact, WWII as a conflict that started on September 1 , 1939, and involved the majority of the nations of the globe, was described almost like an event that was happening in parallel to the Great Patriotic War.

${ }^{16}$ Пётр Игнатов, Записки партизана. Кн. 1: В предгорьях Кавказа (Москва: Молодая гвардия, 1944); Александр Покрышкин, Крылья истребителя (Москва: Воениздат, 1944); Александр Штепенко, На дальнем бомбардировщике (Москва: Воениздат, 1945); Сидор Ковпак, От Путивля до Карпат (Москва: Воениздат, 1945).

${ }^{17}$ In the paper all names of the memoirists is given in Russian tradition, according to Russian editions of their books.
} 
(Izdatelistvo DOSAAF SSSR), «Molodaya Gvardiya» Publishing House of the Central Committee of the All-Union Leninist Young Communist League, «Sovetsky Pisatel» Publishing House («Soviet Writer») and etc. War veterans' reminiscences were released by publishing houses of the Soviet republics, first of all, by Political Literature Publishing House of Ukraine (Politizdat Ukrainy), Minsk Publishing House «Belarus» and «Sovetskaya Rossiya» Publishing House of the Russian Federation. Some regional publishing houses also took part in the process, for example, Gorkiy VerhneVolzhskoe Publishing House and Krymizdat («Tavria»).

The complete bibliography of the wart memoirs publications has not been compiled yet" ${ }^{18}$. According to my quite rough estimation, around 2,000-3,000 books were published in 1945-1991 (excluding publications in the magazines and republications). The number of printed copies in regional publishing houses reached 10,000-50,000 copies, while the central ones reached 65,000-200,000 copies. Some books were republished 2-3 times and even more, for example, Georgy Zhukov's «Vospominaniya i razmyishleniya» («Reminiscences and Thoughts») were republished ten times (within the period of 1969-1991) with total run of around two million copies.

Texts that are presented on the biggest war literature site in Russian, Militera" $^{19}$, complemented with books from my personal collection are the basis for this article. In this paper I intentionally focused on publications in Russian released in 1945-1985 only, excluding the books published in the languages of other nations of the USSR. I do not have intention to cover the whole scope of the Soviet war memoirs in this paper, the goal is, first of all, to state the research problem and to broaden the traditional canon of the «Holocaust literature of the Soviet time» owing to new genres introduction into the researchers' field of vision.

Mass publication of war memoirs can be considered as a part of the creation process of the «the Soviet people heroic deeds during the Great Patriotic War» myth. The reminiscences were written $\left(\right.$ or signed $\left.{ }^{20}\right)$ by the great

${ }_{18}$ In this regard some amateur efforts were made. For example, site amyat.narod.ru includes a quite detailed list of published memoirs with stories about Soviet aviation (http://www.amyat.narod.ru/ bibliography/memo.htm,) containing around 400 books about WWII published in 1945-1991.

19 «Милитера: Военная литература», accessed December 29, 2018, http://militera.lib.ru/memo/ index.html.

${ }^{20}$ I meant quite a lot of texts that were published as memoirs, but in fact they did not belong to this genre and, at the best, they described the battle route of the military unit where the author served presented in the completely formal way. As an bright example I can name the book «Zemlya v ogne» ("The Earth is on Fire») (1975) by Ivan Yakubovskiy, a commander-tankman, twice Hero of the Soviet number of the famous Soviet military leaders, Heroes and twice Heroes of the Soviet Union, as well as by war veterans who sat high after the war.

No doubt the creation and publication of the memoirs were accompanied by censorship and self-censorship. This is regarding the avoidance of the «inconvenient» issues and moments, as well as leading the description to the required narrative. For example, the losses of the Red Army were not mentioned at all in the reminiscences of the Soviet military. The most open authors wrote about «big» or «heavy» casualties in their army units, but they never mentioned the numbers. Besides, it was necessary to follow the official interpretation in the description and characterization of the wartime events. Thus, General of the Army Semen Ivanov in his memoirs, published in 1990, described the problems his friend Ivan Bagramyan faced (twice Hero of the Soviet Union, a Marshal of the Soviet Union, a Deputy Minister of Defense of the USSR, a member of the Central Committee of the CPSU),

My elder friend was in real anguish at not being able to present his sincere thoughts and opinion regarding some issues of the last war in his written materials, because there were a lot of restrictions when the books were published... He said, «You, Semen Pavlovich [Ivanov], ten years younger than I am and, probably, you will live to see when it is finally allowed writing about the war more truly. Then try to correct unintentional misrepresentation and omissions of those who passed away too early»".

According to S. Ivanov, I. Bagramyan when he openly spoke about the reasons of the failure of the Soviet offensive operation near Kharkiv in spring 1942 mentioned that the intelligence info about the foe had to be «tailored» to fit Stalin's opinion about strategic situation. But the commander had to distort conclusions long after the end of the war. S. Ivanov cites his words,

It came back to haunt me much later, in 1976-1977, when the typescript of my book «Tak shli myi k pobede» («The Way We Headed toward Victory») was on its way to publishing. Some text in it I had to literally mutilate to squeeze in «facts» supporting the idea that Stalin allegedly had sufficient reasons to believe that the enemies, like in the fall of 1941, would direct the main attack on Moscow in 1942.

Petr Vershigora in the foreword (1963) to Dmitriy Medvedev's «Silnyie duhom» («Strong in Spirit»), may be the most popular edition

Union during the war, and a member of the Central Committee of the CPSU and a Marshal of the Soviet Union after the war.

${ }^{21}$ Семён Иванов, Штаб армейский, штаб фронтовой (Москва: Воениздат, 1990), 252.

${ }_{22}$ Иванов, Штаб армейский, штаб фронтовой, 253. 
of the partisan memoirs, expressed his opinion in pre-Perestroika conditions more covertly,

Literary atmosphere D. Medvedev had to work in was extremely unfavorable. It was not easy for him to describe everything he saw, felt and experienced ${ }^{3}$.

The story of publishing and editing of Georgy Zhukov's «Vospominaniya i razmyishleniya» («Reminiscences and Thoughts») is the most documented one for war memoirs. Aleksandr Yakovlev Fund published documents demonstrating that the content and the corrections necessary to bring the text into compliance with the official opinion were approved at the level of the members of the Central Committee of the CPSU ${ }^{24}$.

However, edited were not only the reminiscences important from the ideological point of view. As example I can name the memoirs «Cherez vsyu voynu» («Through the Entire War») by former Border Troops officer Mihail Padzhev as an example when the «improper» everyday episode was removed. One page was lost in the copy of the first edition of this book (Politizdat, 1972) kept in my personal collection. An attempt to find out what text was printed there led me to unexpected finding: in the second edition (1976, and in 1983 the third edition was released) the text that supposed to be in that page was omitted. Upon examination of the intact copy of the first edition, it was found out that a story about a Hungarian officer captured by the Border Troops and their friendly attitude to him was removed from the book - an «ideologically harmless» episode one would think. At the same time, I assume, the lack of the page in my book is not the result of vandalism of the previous book's owner, but the result of an «editing» of the already printed books.

But it would not be fair to say that the Soviet censorship of war memoirs was total. Among books with reminiscences it is possible to find quite undisguised ones describing commanders' mistakes or telling the «foxhole truth», with specifying of the number of casualties, alcohol abuse and other facts that were not always positive for the image of the «people - winner of the Fascism». I would call the following books among the most spectacular examples: «Nad kartoy byilyih srazheniy» («Over the Map of Bygone Battles») by Mihail Kazakov (Voenizdat, 1965), «Byila voyna» («It was the War») by Aleksandr Lesin (Simferopol: «Krym», 1968) and «Dorogie

\footnotetext{
${ }^{23}$ Пётр Вершигора, «Герой о героях», в Сильные духом, авт. Дмитрий Медведев (Киев: Политиздат Украины, 1978), 4.

24 «Фонд Александра Н. Яковлева. Архив Александра Н. Яковлева», accessed December 29, 2018, http://www.alexanderyakovlev.org/fond/issues/parts/62029/62043.
}

moi saperyi» («My Dear Sappers») by Igor Nikolaev (Voenizdat, 1965). The similar reminiscences can be found dispersed among many other texts.

\section{Holocaust Hushing up in the Memoirs}

Taking into account the tradition of Holocaust issue hushing up in the Soviet public sphere, a phenomenon well-studied in historiography, and vigilance of the soviet censorship, absence of allusions to Nazi genocide against Jews or cases when the problem was camouflaged in the memoirs as stories about the fate of «the Soviet civilians» are not surprising ${ }^{25}$.

One of the most striking examples of such kind is «Oruzhie osobogo roda» («The Weapon of Special Kind») by Konstantin Kraynyukov (1977, 1978, and 1984 - hereinafter I specify the dates of the books publishing and republishing), a member of the Military Council of the $1^{\text {st }}$ Ukrainian Front ${ }^{26}$. When describing the political work organization during the fighting in Poland in 1945, he told the story about Auschwitz death camp (in the texts of the Soviet period it was mentioned as Oswiecim, according to the Polish name of the locality) on ten pages of his book. The political worker described in detail the camp facilities, medical experiments on the camp's prisoners, and organization of killings. But the ethnicity of the victims was mentioned in general, «more than 4 million of the Soviet and Polish prisoners were perished here, as well as citizens of Czechoslovakia, Yugoslavia, Greece, France, Italy, the Netherlands, Hungary, Romania, Denmark, Belgium and other countries»". Ivan Katyishkin, an officer of the staff of the $59^{\text {th }}$ Army, shared his impressions (1979) after visiting Auschwitz. While describing the horror of what he saw, he wrote about the victims of the camp in the same way, «perished were more than 4 million of the Polish, Soviet and other citizens of the European countries enslaved by Hitlerites» and among the liberated prisoners he met he mentioned «Poles, Russians, French, Belgians, Czechs, Slovaks, Hungarians, and Romanians» ${ }^{28}$.

${ }^{25}$ However, I would like to stress, that the «hushing up» concept shall not be attributed to all the memoirs that do not contain any reminiscences about the Holocaust. On the one hand, we shall take into account that not all the authors directly encountered the Holocaust in their wartime life (for example, sailors or soldiers who served in the North), on the other hand, it is necessary to take into account the author's strategy in every particular text. When describing their wartime lives, not all the memoirists considered it necessary to mention the facts that were beyond the framework of their command post or place in the trench. Hence, «hushing up» in the article means only the intentional avoidance of mentioning or deliberate «blurring» of the victims' Jewish descent when describing Nazis' crimes.

${ }^{26}$ The post of a member of the Military Council of the Army or Front approximately was equal to the post of a Deputy Commander for Political Issues.

${ }^{27}$ Константин Крайнюков, Оружие особого рода (Москва: Мысль, 1984), 355-364; quote Р. 360. ${ }^{28}$ Иван Катышкин, Служили мы в штабе армейском (Москва: Воениздат, 1979), 175-176. It looks like K. Kraynyukov and I. Katyishkin borrowed these words from the article "Oswiecim (concentration 
In the memoirs of Nikolay Popel (1970), a member of the Military Council of the $1^{\text {st }}$ Guards Tank Army, there was a quite wordy episode about recently liberated Majdanek camp. While describing in details everything he saw and heard about the crimes that were committed there, the political worker wrote the following, «Russians, Poles, Jews, Italians, Czechs, Ukrainians, Greeks, Serbs, Lithuanians, Albanians, Latvians, Byelorussians were killed here - one and a half million people»" ${ }^{2}$. In much the same fashion, Jews were mentioned among other ethnic groups by Amazasp Babadzhan$\operatorname{yan}^{30}$ (1972 and 1975) who visited Majdanek as a part of the same group. He informed the readers that «more than one and a half million of Russians, Poles, Jews, Byelorussians, French, and Czechs were killed there»" ${ }^{31}$ To be fair, immediately after the episode about Majdanek A. Babadzhanyan mentioned Jews as a special category of Nazis' victims. The author weighed in on the debate with H. Guderian who tried to «whitewash» and disassociate himself from Nazis' crimes in his book. Among crimes of Nazi military A. Babadzhanyan mentioned «The Commissar Order» (Kommissarbefehl), according to which the Nazis shot down the Soviet prisoners of war «who belonged to political staff of the Red Army, communists and Jews ${ }^{{ }^{32}}$. Nevertheless, N. Popel also mentioned the special treatment of Jews by Nazis, though the reference was not accented. On the eve of assault of Poznan, the author of intelligence report informed about ethnicity policy in the city pointing that the local Gauleiter «officially declared that «the Poles came second after the Jews as racial inferiority» ${ }^{33}$. N. Popel expected that, probably, the readers had sufficient background knowledge to «decrypt» such message.

In memoirs (1982) of Vasiliy Boyko, a member of the Military Council of the $39^{\text {th }}$ Army, was used the similar strategy of «blurring» Jewish ethnicity of the majority of the victims. When describing the Nazis' crimes in the Lithuanian Kaunas, which his army took, he wrote the following about the Ninth Fort, «dozens of thousands of Russians, Lithuanians,

camp)» of the Great Soviet Encyclopedia (K. Kraynyukov's text that almost word for word agrees with the Encyclopedia's one is added by allusions to victims from Greece, Denmark and Italy that were not mentioned in the Encyclopedia) or some other similar publications.

${ }^{29}$ Николай Попель, Впереди - Берлин! (Москва: издательство ДОСААФ, 1970), 115-118; quote P. 117.

${ }^{30}$ He was commander of the $11^{\text {th }}$ Guards Tank Corps in the 1945 and chief of Tank Troops of the Soviet Army and member of the Military Council of the Ground Forces at the time of the memoirs publishing.

${ }^{31}$ Амазасп Бабаджанян, Дороги победы (Москва: Молодая гвардия, 1975), 214.

${ }^{32}$ Бабаджанян, Дороги победы, 214.

${ }^{33}$ Попель, Впереди - Берлин!, 195.
Poles, Dutch, Belgians, French, Czechoslovaks and Austrians were killed here. Old people, women and teenagers were exterminated. Children were buried alive» ${ }^{34}$. Fifty thousand of the Jews that were killed there by Nazis were not mentioned among the victims. Nevertheless, literally in the next paragraph the author mentioned them when talking about Ukmergè town, where «since 1941 thousands of Lithuanians, Russians and Jews were languishing in the dungeons. After the ruthless torture Gestapo men brought groups of 50-100 people to the forest by preliminary dug pits and shot them with machine-guns till they perished 12 thousand people» ${ }^{35}$. According to the latest data more than 10,000 Jews were killed in the town ${ }^{36}$, but the memoirist mentioned them at the end of the list of victims ${ }^{37}$.

Probably the text (1974) by Semen Borzunov, a former military reporter, even is more revealing. In the memoirs he described Nazi regime in the occupied Kyiv. The story of a girl who managed to cross the front line became the basis for the episode. Apart from exporting the working force and valuables the Nazi organized mass killings in the city, «now they prepare the massacre of civilians. Night and day they drive people together, many elderlies and children among them, to Babi Yar and brutally exterminate them. Machine-guns don't stop to fire whole days. Children are thrown to the pits alive and immediately covered up with soil. Young people are dispatched to Germany for hard labor» ${ }^{38}$. As we can see there was no even the slightest hint on the victims' ethnicity.

So, the given examples quite agree with the Soviet official position of Holocaust hushing up. Nevertheless, in line with such «ideological right» descriptions it was possible to find mentions to Jews as a separate category of Nazi victims.

\section{Frontline Terseness}

In war veterans' reminiscences when the issue of the anti-Semitic component of the Nazi ideology and victimization of Jews was covered in the text

\footnotetext{
${ }^{34}$ Василий Бойко, С думой о Родине (Москва: Воениздат, 1982), 192.

${ }^{35}$ Бойко, С думой о Родине, 192.

36 «Holocaust atlas of Lithuania», accessed December 29, 2018, http://www.holocaustatlas.lt/ EN/\#a_atlas/search/vcntfr=5000/page/1/item/69/.

${ }^{37}$ The further mentioning of the town in this book is noteworthy. When praising the development of the socialist Lithuania after the war, V. Boyko mentioned as an achievement that in Ukmerge «nothing is left from the sad memory of old-time gloomy suburb Peski where Hitlerites tortured to death thousands of the Soviet citizens. At this very place a new housing complex was built with beautiful and comfortable houses». (Бойко, С думой о Родине, 219).

houses». (Бойко, С думой о Родине, 219).
${ }^{38}$ Семён Борзунов, С пером и автоматом (Москва: Воениздат, 1974), http://militera.lib.ru/memo/ russian/borzunov_sm01/index.html.
} 
it often was not pronounced. However, at the same time, the «transient» allusions of this kind demonstrate authors' understanding that the anti-Jewish component can be considered separately.

Thus, Aleksandr Altunin" (1981 and 1985), who entered the war as a lieutenant and a company commander in summer 1941, conveyed the words of his deputy for political issues. While reading the army newspaper «Za chest Rodiny» («For the Honor of the Motherland»), the political commissar was exasperated by Hitler's word cited in the newspaper,

Stadnyuk blasted off, "What a scumbag! Such a mean and cruel animal decided to conquer the world! Just listen to what Hitler declares, «A human being dies from the peace, a human being flourishes only owing to the war... If there were no Jews, they would have to be inventedonly the cruelty makes human being move... Who can question my right to exterminate millions of people of the inferior race who reproduce like insects?»...»".

In this very episode the allusion to Jews could be removed from the quotation, if required, without much detriment of the meaning. Important is that it is unlikely that the memoirist remembered his friend's remark word for word uttered forty years ago, but while reproducing it, he maintained the «Jewish accent».

Allusions to Nazis' special attitude to Jews can be found in memoirs in episodes describing interrogations of the captives or examining of trophy materials. Ahill Bankvitser in his memoirs (1962) described an interrogation of a gefreiter captured in 1941. When profiling a Hitlerite, the memoirist noted that the interested motives were the main reason for the captive's sympathy with Nazis, «When Nazis took the driver's seat of the Third Reich, they allowed their supporters to rob Jews and anyone who was unhappy with the new authorities»". Captives caught near Smolensk said during an interrogation witnessed by Nikolay Moskvin (1971) that they sincerely believed «they came to liberate us from Jews and commissars»"

Mihail Burtsev who was the Head of Special Propaganda Dept of the Chief Political Directorate of the Red Army (for propaganda among

${ }^{39}$ When the memoirs were published, the author was a General of the Army, a member of the Central Committee of the CPSU and a head of Civil Defense of the USSR - a Deputy Minister of Defense of the USSR.

${ }^{40}$ Александр Алтунин, Повесть о тревожной молодости (Москва: Военное издательство Министерства обороны СССР, 1981), 104.

${ }^{41}$ Ахилл Банквицер, Люди нашей дивизии (Москва: Воениздат, 1962), 103.

${ }^{42}$ Николай Москвин, Партизанскими тропами (Москва: ДОСААФ, 1971), 14-15. enemy troops) described the episode with examination of the trophy materials collected in Stalingrad,

All of a sudden a few lines heavily underlined attracted my attention: «But if we lose this war, they will take vengeance on us for everything we've done. Thousands of Russians and Jews shot together with their wives and children near Kyiv and Kharkiv...» "Probably such thoughts came to the mind of not only this soldier», I thought ${ }^{\text {t3 }}$.

In Aleksandr Sviridov's memoirs the reference to Nazis' anti-Semitic ideology appeared in connection to the coming attack on the fortified defense Wotan line on Molochnaya river. The memoirist mentioned the words of the head of regiment intelligence who explained the name of the defense line, «Pagan cult of Wotan the fascist countered to Christianity as a religion of the Jewish origin»".

Petr Teremov, a commander of the $108^{\text {th }}$ Rifle Division, also kept back the motives of behavior of the German soldier badly wounded and captured in 1944. He was brought to medical battalion where surgeon Volf Kaplun «ordered to bring him to operating table. The fascist noticed that it was a Jew who bent over him and spat in the face of the doctor ${ }^{45}$. Nevertheless, the doctor saved life of that Nazi. When P. Teremov recollected his time in occupied Babruysk at exfiltration in 1941, he cited words of one of the «New Order» supporters. In response to the remark about possible shooting for breaking curfew, this person said, «Nobody kills people, only communists and Heebs are killed»"

Allusions to killing Jews by Nazis could also be a part of description of Nazis' crimes revealed at the liberated territory of the Soviet Union and European states. Thus, military justice officer Nikolay Chistyakov (1979) when he described trial held in Krasnodar in July 1943 of Nazi criminals who exterminated «dozens of thousands of the Soviet citizens» mentioned some episodes of this crime, «during two days - 21 and 22 August $1942-$ the Hitlerites exterminated almost all Jews" ". More detailed was story about Jews extermination in Kislovodsk was given in the book by military reporter Pavel Kovanov (1975, 1978, and 1982). When the author visited the city immediately after its liberation, he listened to the stories about the Nazi terror, including the fact that

\footnotetext{
${ }^{43}$ Михаил Бурцев, Прозрение (Москва: Воениздат, 1981), 132.

${ }_{44}^{44}$ Александр Свиридов, Батальоны вступают в бой (Москва: Военное издательство Министерства обороны СССР, 1967), 113.

45 Пётр Теремов, Пылающие берега (Москва: Воениздат, 1965), 155.

${ }^{46}$ Теремов, Пылающие берега, 171.

${ }^{47}$ Николай Чистяков, По закону и совести (Москва: Воениздат, 1979), 90.
} 
During the first days of occupation a «Jewish Committee» was created. They made all Jews to register and give all the valuable things away, and then they moved more than two thousand of people out of the city and shot them. Many Jewish families committed suicide without waiting for the racking massacre... The family of doctor Faynberg came to a horrible end. He, his wife and daughter slit their wrists and took morphine trying to commit suicide. Nazis sent them to the hospital where they got well and then Nazis shot them ${ }^{48}$.

The author mentioned that in Armavir Nazis « exterminated all Jews, shooting communists and families of Red Army commanders»"

Mihail Padzhev, a Border Troops officer, while describing the beginning of the war $(1972,1975$, and 1983) mentioned one of the German leaflets he happened to hold in his hands. It offered, «to surrender and to deliver NKVD employees, commissars and Jews»". Other «Jewish» episodes of the book were connected to the time when the border guards returned to Western Ukraine in 1944. In the city of Sniatyn the battalion was deployed where the author was appointed as Chief of Staff. When he described the place of dislocation, he mentioned just one detail,

One of the streets met us with a lonely deserted. Windows and doors in the houses were wide open, words «Jewish ghetto» loomed black on the white walls. Coils of barbed wire were lying next to them. Piled were children footwear and clothes ${ }^{\text {s1 }}$.

Moving further in the rear of the advancing troops the border guards reached the boundary of 1939 , i.e. the location they had to retreat from in 1941. There Captain Vasilchenko met his old friends - a family of the teacher of Jewish ethnicity from the village of Bitlia.

When the war started the teacher's family could not evacuate. And for almost three years they were hiding in the woods. Two Hutsuls families from Bitlia and Husnya helped this Jewish family. They supported this family, provided them with clothes and food, and let them stay in their houses in winter. This way the Jewish family managed to survive the fascist occupation $^{\text {s2 }}$.

The wording M. Padzhev used conveying the said episode to the readers is of interest. He expressed his regret for «not having the opportunity

\footnotetext{
${ }^{48}$ Павел Кованов, И слово - оружие (Москва: Советская Россия, 1982), 206.

${ }^{49}$ Кованов, И слово - оружие, 220.

${ }^{50}$ Михаил Паджев, Через всю войну (Москва: Политиздат, 1983), 142.

${ }^{51}$ Паджев, Через всю войну, 241.

${ }^{52}$ Паджев, Через всю войну, 273.
}

to meet the patriots who were risking their lives and the lives of their children to help to survive the Jewish children, their father and mother. I wanted so much to thank them for their patriotism [italics is mine - D. Sh.] and courage! $»^{53}$. Obviously, the choice of definition is improper, but it looks like neither the author, nor the editor had any doubt that the rescue of Jews could be taken as manifestation of one's love to the (socialist) motherland.

Allusions to Holocaust are also occurred in connection with stories about participation in the operations at the territory of Europe. For example, Grigoriy Kostyukovskiy (1959), a signal corps officer, described the heartwarming encounter of the Soviet soldiers with local Romas during the battles for liberation of the Hungarian town of Ózd. The author gave quite a short explanation why they were so happy, «fascists were exterminating Gypsies as much as they exterminated Jews». I believe this episode is rather characteristic - the author was not sure that the readers were aware of the Romas persecution by Nazis, but he thought that the reference to the fate of the Jews would explain everything for them ${ }^{\text {s4 }}$. Ivan Zamertsev, a Soviet Commandant of Budapest, mentioned the fate of the Hungarian Jews in his memoirs, «when Hitlerites occupied Hungary in March 1944, they created Jewish ghetto in Budapest and other cities of the country... Fascists managed to shoot many hundreds of people». The author had to take care about the survivorss. Warsaw ghetto was mentioned in Stanislav Poplavskiy's book (1963 and 1974). The episode is quite laconic: the author described his meeting with Wanda Wasilewska in the street of the Polish capital. The writer was shocked with something - an officer accompanying her explained, «She visited the place where Jewish ghetto was... She was really shocked with what she saw and found out there...» ${ }^{56}$. The way Vladimir Belyavskiy (1973) mentioned Holocaust in his memoirs is quite interesting. He mentioned his visit to Majdanek giving the remark about its victims in the same manner as it was described above, without mentioning the Jews. But in the next paragraph he described gratitude of Poles for liberation of their country using as an example one episode that, presumably,

\footnotetext{
${ }_{53}^{53}$ Паджев, Через всю войну, 273.

${ }^{54}$ Григорий Костюковский, Напряженная линия : записки военного связиста (Москва: Воениздат 1959), http://militera.lib.ru/memo/russian/kostyukovsky_ga01/index.html.

${ }^{55}$ Иван Замерцев, Через годы и расстояния (Москва: Воениздат, 1965), 97.

${ }^{56}$ Станислав Поплавский, Товарищи в борьбе (Москва: Воениздат, 1974), 156. In spite of the fact that the memoirs belong to the General of the Armed Forces of the Republic of Poland, the text, no doubt, belongs to the Soviet war memoirs cohort. Their author was a Soviet General who served in the Armed Forces of the Republic of Poland from 1944 through 1956.
} 
was borrowed from a political report. When command center was in the city of Żelechów,

Polish citizen Vorohovich came to the Political Department of the army.

- Fascist scums killed and tortured to death almost all Jews in our city. Now only 130 of us left. We shall thank the Red Army for liberation...".

Morits Sokolov, a Soviet political worker, headed the German-language newspaper «Tägliche Rundschau» published in Berlin after the war. When he described his search for a print shop for his newspaper, the memoirist (1979) wrote a story about a company the production facilities of which were of interest for him, «The company is considered to be Jewish and when Hitler came to power it was aryanized, some of its owners fled abroad, some of them died in Buchenwald ${ }^{\text {ss. }}$. A bit further when describing the meeting with German activists, the readers of the newspaper, the author included into the text the phrase of one of them that demonstrated components of the Nazi terror, «mass arrests, tortures in Gestapo, Jewish pogroms, concentration camps with hundreds of thousands of prisoners»". Mihail Padzhev described another episode connected to his post-war service in Germany. Border guards were informed that Graf Schulenburg (a former ambassador to the USSR) appeared in his castle. When they moved to arrest him, they found there a man much younger than the Graf. It was his son. The young Graf could hardly be accused of collaboration with Nazis, «we found out that when fascists started extermination of the Jews in Germany, young Schulenburg immigrated together with his beloved girl of Jewish ethnicity and, thus, saved her» ${ }^{\circ}$.

\section{Jewish Pain}

Among soviet war memoirs focusing on Holocaust issue is possible to find in texts of militaries of Jewish origin. Jews persecution by Nazis was the part of their own tragedy and tragedy of their families.

Pavel Shafarenko (1978), a commander of airborne brigade, happen to visit his native town of Putyvl in retreating in fall of 1941. The description of the episode points out for the readers that inhabitants were aware of Jews extermination by Nazis,

Out of all my friends and people I know almost nobody stayed in the town... Just an old man Levitin who worked at the hair salon

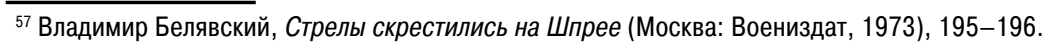
${ }^{58}$ Мориц Соколов, «Оружием слова», в На земле, в небесах и на море (Москва: Воениздат, 1979), 153.

${ }^{59}$ Соколов, «Оружием слова», 159.

${ }^{60}$ Паджев, Через всю войну, 302. on the market place... He and his wife remained in Putyvl though he had heard that fascists killed all the Jews. However, he tried to assure even me that Nazis would not reach our town. Later I received a letter informing me that the Levitins were killed immediately after the Nazis captured the town ${ }^{61}$.

There were no further allusions to Holocaust issue in Shafarenko's book except for one short episode. The writer described his impressions from liberation of Polish land he had to pass through, «Warsaw looked like almost razed to the ground. And a red brick wall of Jewish ghetto spun through it like a trail of blood» ${ }^{{ }^{2}}$. Metaphoricity emphasizes the importance of this allusion for the author.

David Dragunskiy while being the commander of tank brigade was twice decorated as a Hero of the Soviet Union. After the war he became a Colonel General of the Tank Corps (1970) and a member of the Central Auditing Commission of the CPSU Central Committee (1971). D. Dragunskiy took part in the activity of the Jewish Anti-Fascist Committee and suggested to start actions on memorialization of the mass killing sites ${ }^{63}$; since 1983 (from the moment of its establishing) he headed the Anti-Zionist Committee of the Soviet Public.

Dragunskiy's book «Godyi v brone» («Years in Armor») was published three times (1973, 1975, and 1983). The memoirs contained several episodes about Holocaust; their presentation, in my opinion, is the very effective demonstration of the attempt to describe personal tragedy without going beyond the limits of the official discourse.

When Dragunskiy found out that the front line came closer to his native place in 1941, he became anxious about the future of his relatives, knowing for sure what would happen to them in case Nazi occupied the place,

I was thinking about the future of my father, mother and sisters. I had to do something to save them, I decided to send to my folks a telegram when the classes were over that they must obligatory to evacuate - the fascists would not spare them ${ }^{64}$.

Further in few pages Dragunskiy described his childhood in his big Jewish family. There is no information in the memoirs why his family did not leave their village of Svyatsk, but he told in details what happened to them

${ }_{61}$ Павел Шафаренко, На разных фронтах : записки командира дивизии (Москва: Воениздат, 1978), 22.

62 Шафаренко, На разных фронтах, 222.

${ }^{63}$ Альтшулер, «Деятельность евреев по увековечению памяти о Холокосте в Советском Союзе в эпоху Сталина», 172.

64 Давид Драгунский, Годы в броне (Москва: Воениздат, 1973), 7. 
when the Nazis came. While recovering after heavy wound in the hospital of Zheleznovodsk, Dragunsky met Petr Usov, his fellow-villager and childhood friend. Petr Usov told him about death of his relatives,

I wanted to keep back, but I cannot. Be strong, buddy. You do not have any family anymore. Fascists shot your dad and mom, and Sonia with children, and Anna, and they did not spare your granddad and nana. Together with them my brother Vania and our friend Grisha Sapozhnikov died too ${ }^{65}$.

Dragunskiy described this news as a death-blow to his hopes, but not as something unexpected,

For quite a long time I suspected that my relatives and close ones were dead. But I did not want to believe it. When we freed Ukrainian cities and villages, we saw the traces of fascist crimes many times. And I was at Babi Yar in Kyiv. I saw endless rows of gallows, graves, corpses and ruins along the roads of fascist retreat ${ }^{66}$.

Then Dragunskiy wrote that he had met his friend few days later and described in more details his story about the tragedy,

All my relatives and all Svyatsk's Communist Party activists were shot on January 25, 1942. The invaders killed everyone who dared to protest against their brutal order. They mercilessly exterminated old people, women and children. 74 people out of those who were killed had name Dragunskiy. There were my parents, sisters and brothers, my uncles, my relatives and close ones...".

The way the information was presented is worth noticing - the accent about Jewish origin of the most victims that were shot was removed. In the first Usov's story it was mentioned that Usov's relatives of Russian ethnicity had been killed together with the Jews. In more detailed story huge Dragunskiy family was mixed with Communist Party activists and those «who dared to protest against brutal order» of Nazis. The author emphasized Jewish origin of part of victims only through the story about his mother, though the story itself included some references to the traditional propaganda subject of Soviet people's friendship, «Russian neighbors of my mother were hiding her for a long time risking their lives. But, nevertheless, the fascists found her». When Dragunskiy described the procedure of public execution, he included the words of the SS man, «Hey, Jewess /in Russian used «iudeyka», word which refers to confession, but not to ethnicity - D. Sh.J,

$\overline{{ }^{65} \text { Драгунский, Годы в }}$ броне, 171

${ }^{66}$ Драгунский, Годы в броне, 171.

${ }^{67}$ Драгунский, Годы в броне, 171. curse you sons and we will free you!» ${ }^{68}$. But the mother's answer completely corresponded to the spirit of the Soviet patriotism, «I bless my sons, I bless the sons of Russia to fight the hateful foes...» and

Burst of sub-machine gun fire ended the life of my mother, a Soviet woman, who knew deep in her heart what people's friendship and love to the Motherland mean... She was not only the mother, but the Soviet patriot as well...".

Most likely it was not the author who «blurred» the Jewish accent in this episode. But further in his book Dragunskiy managed to hint at the special Jewish motive of his payback to Nazis. While mentioning the fierce resistance of the enemies during Berlin assault, Dragunskiy wrote about the reasons of such resistance,

They knew that it was time for vengeance for all the crimes: for millions of victims of Oswiecim and Dachau, Mauthausen and Buchenwald, Warsaw ghetto and Babi Yar, Lidice and Oradour, and those with blood on their hands fought desperately, they did not surrender ${ }^{70}$.

In freed Prague the memoirist described his encounter with emaciated prisoners of Theresienstadt concentration camp «where around twenty thousands of Jews were in their final days». Most of them were girls and the author «could not look at them without trepidation, it seemed to me that my sisters are among these people»". Another episode with freed Jews was about the period when there were fights in Silesia. In the outskirts of the freed small town a cellar was found where

...in the light of flash-lights and torches the soldiers saw an awful scene: ragged, scruffy, emaciated and feral people and dozens of decomposing corpses. They were the Jews who escaped from Warsaw ghetto with the help of the Poles. Around a hundred people escaped, but only twenty three survived. Almost two years these people were wandering in the woods, hiding in the ravines, underground caves and catacombs ${ }^{12}$.

${ }_{68}$ Драгунский, Годы в броне, 172. Most likely the word «iudeyka» camouflaged the offensive word "zhidovka» (Heeb). It is worth mentioning that the second edition included two additional phases placed before this one,

- «And how many sons do you have, iudeyka?»

My mother looked at him scornfully:

- «Millions. Children of all mothers are my children».

- «Where are your sons?»

- «Fighting against you, fascist scums». (Quote P. 178).

${ }^{69}$ Драгунский, Годы в броне, 172.

${ }^{70}$ Драгунский, Годы в броне, 278.

${ }^{71}$ Драгунский, Годы в броне, 353.

${ }^{72}$ Драгунский, Годы в броне, 250-251. 
To summarize, I would underline that the majority of the short allusions to Holocaust made by war veterans demonstrate us the situation of «unspoken memory»: the authors were aware of Jews extermination by Nazis, but they did not describe it in details. Short allusions in the memoirs touched upon different aspects of Holocaust - ideology, mass shootings and death camps. The style of such allusions without any additional explanation assumed some kind of background awareness of the readers. In the memoirs of the war veterans of Jewish descent Holocaust events were described, first of all, as a personal tragedy. At that, all the description in general did not go beyond the limits of the official Soviet discourse.

\section{Prisoners of War}

Apart from war veterans' texts, reminiscences about captivity were one of the components of the Soviet war memoirs. Most of them were published during the Khrushchev Thaw. Though during post-Stalin period the issue of the captivity became open for the public, only two aspects of this issue were used: emphasizing of brutal attitude to the Soviet prisoners of war and stories about their unbroken will to resistance. These very topics were the main ones in all the memoirs of the former prisoners of war published during the Soviet period. The stories about the captivity were often included into the partisan memoirs (in the form of a story how the author or his comrades-in-arms got to the partisan unit). Quite often the stories about prisoners of war of Jewish origin were the part of the captivity issue.

Ivan Berezhnoy (1976) wrote the following when he was telling the story about his brother-in-arms from the partisan unit, Aleksandr Nepomnyaschiy, who was an assistant group commander for artillery supply in 1941. «In autumn nineteen forty one when breaking out near the city of Yahotyn, he was wounded and captured. Hitlerites shot abound a hundred of captured commanders, political workers and Jews right in front of his eyes $»^{13}$.

In memoirs (1973) by Ilya Davyidov, who was in a partisan unit during the war, the danger for prisoners of war of Jewish origin was mentioned rather indirectly. When listing the newcomers of the unit, former prisoners of war, he mentioned that among them there was «Efim Solomonovich Faytelson, a Chief Mechanic of «Anti-DuPont» factory, who avoided being shot in the concentration camp by creating the new last and second

${ }^{73}$ Иван Бережной, Два рейда : воспоминания партизанского командира, 2-е изд., испр. и доп. (Горький: Волго-Вятское книжное издательство, 1976), 341. In the first edition of I. Berezhnoy's «Dva reyda: vospominaniya partizanskogo komandira» («Two Raids: Partisan Commander's Reminiscences», 1967), P. 296 there was no episode with biographies. name» ${ }^{74}$. As we can see, the episode is to some extend «unsaid»: Jewish origin of the prisoner of war was not directly mentioned, and there was no explanation why out of the whole group of prisoners he was the one who was at risk of being shot. We can assume that this way the writer tried to avoid problems with censorship, however there is an episode about killings of the Jews below in the book. Most likely we again encounter the situation when the author just expected the readers to have «background knowledge» and believed that it was needless to describe the obvious things for them.

The allusions to danger for prisoners of war of Jewish descent in Andrey Pirogov's memoirs are «unsaid» in the same way. In Volodymyr-Volynskyi officers camp an interpreter of the camp approached him as one of the leaders of the underground organization of the prisoners of war. He was aware of the risk he incurred being under surveillance almost round the clock, but he took guts - he had nothing to lose: «I know I'm done anyway... One of these days they will shoot me. They suspect I am a Jew...»" The story of the memoirist's imprisonment in Sachsenhausen includes the similar episode: an SS man ordered Boris Vinnikov to come to the main secretariat. Everything was clear for Boris and his friends, «We will never see Boris again. Vinnikov is a Jew». However, the prisoner was lucky - the administration just wanted to clarify some info in the financial statement ${ }^{76}$.

In the book (1966) by Andrey Yudenkov who was captured near Vyazma in 1941 an experience of the witness of initial «selection» of prisoners was described,

Almost every morning when the column took up formation, an officer appeared with an interpreter and proclaimed, «Communists, commissars, Jews [Zhydy] and Ukrainians - three steps ahead!» People who belonged to the first three categories naturally did not responded, otherwise it was a death sentence. ... Then the Nazis played the well orchestrated scene: they dragged out of the column one or two prisoners and shot them on the spot stating they were «a commissar», «a communist» or «a Jew».... Their purpose was obvious: they wanted to drive a wedge between prisoners to make them rat out communists, Jews, and political workers".

\footnotetext{
${ }^{74}$ Илья Давыдов, Юность уходит в бой (Москва: Воениздат, 1973), 200.

${ }^{75}$ Андрей Пирогов, Этого забыть нельзя (Одесса: Одесское книжное издательство, 1961), 66.

${ }^{76}$ Пирогов, Этого забыть нельзя, 172.

${ }_{77}$ Андрей Юденков, За огненной чертой (Москва: Воениздат, 1966), 50. Unfortunately, the other books of this writer I could not get: «V ognennom koltse» («Encircled by Fire», 1962), and «V tyilu vraga, vblizi ot fronta» («In the Enemy Rear, Near the Front Line», 1963). It is worth noticing that their author, Doctor of Historical Sciences, wrote some other texts, for example: «Rossiya - rodina leninizma" («Russia - the Motherland of Leninism», 1956), «Mezhdunarodnoe znachenie opyita stroitelstva
} 
Army doctor Ibragim Druyan wrote (1975) about extermination of the POWs of Jewish descent near Kyiv in September 1941.

A German officer [...] ordered all the prisoners to group according to their ethnicity. Several groups were formed: Russians, Ukrainians, Caucasians, and Jews. Nazi immediately brought the Jews to the wirefenced plot of the field and made them stay inside with two guards at the entrances.

Before the dawn German soldiers ordered the Jews to take off their clothes. Those who refused to undress were shot. In the morning, when POWs continued marching, the half-naked prisoners of Jewish decent headed the column; the memoirist did not tell anything about what happened to these people after that. When I. Druyan described the horrors of everyday life in the camp, he mentioned Jews again as a separate category of victims,

In line with mass shootings they tried to corrupt, maim our morality. Rat out commissars and communists, Jews and rebellious prisoners and you will be fed, you will have some extra scoops of thin broth. If you join the police, you will be replete, dressed and shod and will feel your power over others".

As we see in his text I. Druyan, the same way as A. Yudenkov, described Jews betrayal, first of all, as a moral leverage for prisoners.

Vladimir Bondarets, a artillery officer, who was captured near Kharkiv in May 1942, wrote (1960) that when Nazis were collecting prisoners, they just asked whether there any commissars and communists among them and promised to arrange necessary measures to find them among prisoners later ${ }^{\text {so }}$. In details, on two pages, the procedure of Jews exposure was described in the story about prisoners of war camp in Proskuriv (Khmelnytskyi). The camp's commandant came for the morning formation with his shepherd in the beginning of July 1942. After the routine procedure the officers were lined separately and the commandant gave a command, «Jews, front and center!». Since there was no response, the prisoners were ordered

sotsializma v SSSR» («Global Reach of Experience of Socialism Development in the USSR», 1958), "Politicheskaya rabota partii sredi naseleniya okkupirovannoy sovetskoy territorii (1941-1944 gg.)" («Party's Political Activity among the Population of the Occupied Soviet Territory (1941-1944)», 1971).

${ }^{78}$ Ибрагим Друян, Клятву сдержали (Минск: Беларусь, 1975), http://militera.lib.ru/memo/russian/ druyan/02.html.

79 Друян, Клятву сдержали.

${ }^{80}$ Владимир Бондарец, Военнопленные : записки капитана (Москва: Молодая гвардия, 1960), 17. In the book as the date when the text has been written specify 1957. to re-form in rank and take off their trousers - the commandant personally started detection. One victim was found and

... a wild scream cut the air. Trained dog dug its teeth into the poor Jew, and tearing up his hip with its claws dragged him along the drill ground. Frail lad rolled his eyes up and was waving off confusedly trying to get away from the gray beast, but he managed to make just few steps, stumbled and fell down. An awkward lump rolled along the drill ground blackening the soil with stains of blood.

The commandant was running around, laughing huskily and beating the prisoner's head and hands with the handle of the whip. At that very minute there was no difference between him and his four-legged confidant. Just for a second it seemed to me that the long shaved lip jerked up wrinkly baring yellow predator-like fangs.

It lasted for several minutes. When Oberleutnant enjoyed it to the full, he, with some effort, pulled aside the dog stained with blood. Feldwebel calmly shot the prisoner into the ear. Meat wagon men put him on the stretchers. The dog licked its jaws with its long tongue and asked for leash $h^{\text {sich }}$.

After that Nazis again suggested Jews to break ranks - three people responded, they were taken away, the inspection was over ${ }^{\mathrm{s}^{2}}$.

Ivan Homich in details described (1959) the special procedure for Jews detection in his memoirs. He was captured after Sevastopol was surrendered. At the very first day «Germans ordered all commissars and Jews to break ranks» of the prisoners' column. But there was no response, and people from the column went on answering to the repeated questions, «There aren't any of them here» ${ }^{33}$. Later Nazis tried several times to find people of these two categories among prisoners on the way to Simferopol and while they were accommodating prisoners in the Simferopol prison,

Hitlerites every now and then tried to find commissars and Jews, but people were hiding them in the thick of the crowd. They arranged inspections and disgusting examinations. Jews were mercilessly beaten and tortured without any interrogation, political workers were beaten and locked in the underground cells".

The next phase of Jews detection occurred in the Dnipropetrovsk prison, where some prisoners were transferred in September 1942. On arrival

\footnotetext{
${ }^{81}$ Бондарец, Военнопленные, 37.

${ }^{82}$ Бондарец, Военнопленные, 38.

${ }^{83}$ Иван Хомич, Мы вернулись (Москва: Воениздат, 1959), 30.

${ }^{84}$ Хомич, Мы вернулись, 33.
} 
they had to go to the washing-house before being allocated in cells. When the prisoners' clothes were sent to the sterilizer room, Germans approached the naked people and «started pushing the prisoners aside and brutally examining the naked men». The Nazis became suspicious about colonel Vasilev (nothing is said about his ethnicity in the text), «Juden? Jew?». But the prisoners managed to persuade the Nazis that the colonel was Russian. After that the prisoners developed special tactics, «from now on none of our Jewish comrades would ever appear in front [of the rank], they were hidden in the thick of the crowd, in the middle of the rank, and I would say we became quite skillful in it ${ }^{85}$.

The story about extermination of prisoners of war of Jewish descent was also included into the book (1963) by Ivan Krivonogov - a companion of Mihail Devyataev in the legendary concentration camp break in the hijacked German bomber from Usedom island in 1945. When he described his imprisonment in the POWs camp in Lorraine where he was convoyed after being captured in the beginning of July 1941, I. Krivonogov wrote, «Once in winter they started selecting Jews out of the prisoners. They were sent to the punishment cell and then killed» ${ }^{86}$. The life of his friend Lev, Jew by origin, who acted as an interpreter in the camp, was endangered. According to the life-saving tactics, the Nazis were sticking to the visual inspection of the prisoners: they managed to persuade the camp's administration that Lev was a Crimean Tatar". Mihail Tartakovskiy, who helped to David Bakradze, in future one of the partisan commanders from Sydir Kovpak's unit, to escape from the POWs camp, had managed to survive in the camp the same way.

He was fluent in German and Hitlerites used him as an interpreter. Being a Jew, M. Tartakovskiy pretended he was Crimean Tatar nationalist and fascists took him as one of their own ${ }^{\text {se }}$.

Mihail Devyataev's memoirs (1972) did not include any episode with detection of the Jews among prisoners of war. As Holocaust victims were mentioned civilians. When a new group of prisoners arrived to «New Königsberg» («Klein Königsberg») ${ }^{s s}$ camp, they paid attention to the female

\section{${ }^{85}$ Хомич, Мы вернулись, 42-43.}

${ }^{86}$ Иван Кривоногов, Родина зовет : записки офицера советской армии, 2-е изд., доп. (Горький: Горьковское книжное издательство, 1963), 68.

${ }^{87}$ Кривоногов, Родина зовет, 69-70.

${ }^{88}$ Давид Бакрадзе, Кровью героев (Тбилиси: Заря Востока, 1961), 15 ; Давид Бакрадзе, Карпатский рейд (Москва: ДОСААФ, 1968), 15.

${ }^{89}$ Probably this episode mingled in the author's memory with the reminiscences about his further imprisonment in Sachsenhausen. In the second M. Devyataev's book his imprisonment in the camp and children stuff scattered about the camp's yard. The guard explained the prisoners, «Jewish families were here, the people were burned in the incinerators to free the place for you, newcomers»".

A special place among memoirs about the Soviet prisoners of war (and among all the other war memoirs) is taken by David Z. Kagan's book «Rasskazhi zhivym» («Tell it to the Live Ones») (1980 and 1986"). This book is the reminiscences of a military medic of Jewish descent who managed to survive in Nazi POWs camps, but his book is not the typical Holocaust survivor story the way it is understood by westerners. In my opinion, the book is a striking example of how the issue of Nazi persecution of Jews was presented in the Soviet domain ${ }^{22}$. Kagan's text included various aspects of Nazis' attitude to Jews, but in the story of the Jewish author they were not specifically emphasized though their scope was quite big. The book was written, first of all, as the memoirs of the prisoner of war and the Jewish context quite often sounded like the mentioned above «unspoken memory».

Kagan entered the war as an army doctor of the $59^{\text {th }}$ Regiment of the $85^{\text {th }}$ Rifle Division. On $22^{\text {th }}$ of July, his regiment set off by an alert from the city of Grodno in Western Byelorussia to face the enemy. On the fourth day of the war, Kagan was heavily wounded into his leg during air attack and he was brought from the front line to the hospital in the town of Masty. Doctors here were three refuges from Warsaw: «In fall of 1939 they left Hitler occupied Poland along with thousands of Jews and arrived to the Soviet Union»" . Together with some other wounded people the author was moved from Masty to the Shchuchyn district hospital that very next day, on $26^{\text {th }}$ of June, turned to be on the occupied territory. When Kagan got to know about it he destroyed all his documents except for his university diploma.

Soon the wounded people were transferred to the POWs camp in the town of Lida. When the author of the memoires got there, he was wondering,

was described in more details (but the camp in the book was called «Klein Königsberg", not «New Königsberg", and there was no episode with extermination of Jews). See: Михаил Девятаев, Побег из ада (Казань: Татарское книжное издательство, 1988).

${ }^{90}$ Михаил Девятаев, Полет к солнцу (Москва: ДОСААФ, 1972), 49.

${ }^{91}$ Unfortunately, 1980 edition was not available to me.

${ }^{92}$ The place where it was published is worth mentioning - Ashkhabad, the capital of the Soviet Turkmenistan. Most likely Kagan's book was published there because the author lived in the Turkmen Soviet Socialist Republic (his medical research papers were published in Turkmen publishing houses). But I suspect that also on such periphery censorship there was less sensitive with respect to the «Jewish issue».

issue». стан, 1986), http://militera.lib.ru/memo/russian/kagan_dz01/text.html\#t1. 
Do Germans know about my ethnicity? Shall I say I am Russian if they ask? What shall I do with my diploma? Shall I tear it and change my last name? But they can detect who is «Juden» during medical examination. Then how could I prove that I am a doctor? It is possible that Germans will postpone killing the doctors. Thing is that the Jewish doctors from Lida are working here in the infirmary".

Through the stories about those civilian specialists the readers received general information about persecution of Jews - holding of hostages, asking for indemnity from the local Jewish community or establishing of ghetto and ordering to attach yellow stars on their cloths". A separate story was devoted to Sonia, a Jewish girl who received fake documents with the help of the locals.

The following episode demonstrates clearly the style of Jewish narrative interweaving with memoirs. The prisoners of war were moved from Lida camp to Grodno. There Kagan met «soldier from my regiment, an engineer platoon soldier named Kislik»,

«And you are here as well.» I shake his hand firmly, look at his skinny body, Caucasian moustache he did not have earlier...

«I am here for the time being», he answered looking around. «Where have you been wounded?»

$[\ldots]$

We kept silence for a while. Finally I asked, «And who are you?»

Kislik understood what I was asking about, «Armenian. And I am not

Kislik, I am Kislikyan».

I lowered my head.

«And you?» he asked.

«Russian I guess, There in Lida no one caviled at me. I do not know what to do. Either to change my first and last names and get rid of my diploma, or leave everything as is».

«No, how could you threw away your diploma?» Kislik raised his hand. «So far they consider the doctors. Civilian doctors are working here.

So, see you later! - And he went to the corner, close to dirty barrel'.

As we see, the reader can figure out that this dialog is a conversation of two Jews only based to its contents.
Another Kagan's comrade-in-arms, Machulskiy, whom Kagan met later in the camp, in fact was doomed - the administration knew about his origin. Kagan reproached him,

«You could have passed for Georgian or Armenian. Could not you do that?»

In the beginning, I did not want to change anything. And then it was too late. Policemen henpecked me: Juden, Juden...".

Kagan with the help of his friends passed for Russian. Every week a general formation was arranged and the prisoners were formed by blocks, «besides, the prisoners of each block were divided into the groups according to their ethnicity»: Russians, Ukrainians, Byelorussians, Caucasian ethnic groups, Muslim «Asians», «the Juden group was placed aside from the joint column» ${ }^{98}$.

I am constantly included into the Russian group.

...I am in the next to the last row. My eye-glasses are in the pocket: I believe that without glasses I do not look like a Jew so much. The previous formations ended without problems. But this time they might expose me. A policeman might approach, swear dirty and drag me to the commandant. And then to the group of doomed: «Juden...»

No, today I made it".

Once the supervising doctor released the memoirist from formation «for health reasons» Evidently, more rigorous check was expected that very day. Nevertheless, Kagan was in constant fear for his life,

I expect any day that a German soldier will appear at the doorway and say just one word, «Komm! I gave Baranov my parents' address and exchanged the clothes with him. ...I hid a piece of yellow cloth under the lining: in case of the prison break I will sew yellow stars on and I might pass for the local Jew who goes to his work and, thus, manage to beat my way out of the city ${ }^{100}$.

Jews together with political workers, communists and captured fugitives made up a «Special Group» of the prisoners. On July 22, 1942, all of them were brought outside of the city and shot.

In spring 1943 Kagan and other three prisoners managed to escape from the camp and join the partisan unit.
${ }_{94}$ Каган, Расскажи живым.

${ }^{95}$ Каган, Расскажи живым.

${ }^{96}$ Каган, Расскажи живым.

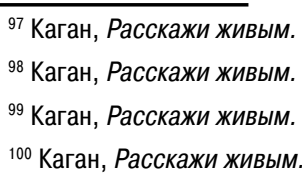

100 Каган, Расскажи живым. 
As we see, «Rasskazhi zhivyim» is a book that does not describe Holocaust as a separate phenomenon, it depicts life of the Soviet prisoners of war. The author due to his descent along with the political workers belonged to the most endangered group of the camp's prisoners; but in the text Jewish origin for Kagan was, first of all, an additional problem complicating his survival among the horridness of captivity that was all the same for the prisoners, it was not a separate part of the story.

\section{Frankness of the Partisans}

The prisoners of war could see mainly what happened within the perimeter. Memoirs of the partisans and members of underground organizations described much wider range of phenomena of life under the «New Order» for the readers. Reminiscences of the partisans when «distributed» as per the service arms hold almost the biggest share of the entire scope of the Soviet wartime memoirs. The general ideological message to be sent to the readers using such publications is obvious: all-people's opposition to the invaders, not only in the field, but in the Nazi occupied territory as well.

On the one hand, the way Holocaust was mentioned in the partisan memoirs could be the same as the above mentioned army «unspoken» way of presenting this genocide, but in general more stories about killings of Jews were included in their books and they commanded a larger part. For example, David Bakradze's memoirs (1968) included reminiscences about the anti-Semitic component of the Nazi policy. In the foreword the author cites various documents that defined Nazi system of terror in the occupied territory, including a fragment of «Ost» plan,

We will manage to wipe out completely the notion «Jews». Some time will be necessary to make such ethnic groups like Ukrainians, Horaken, Sorbs (Lusatians) to disappear from our territory ${ }^{101}$.

When describing the situation in Volhynia in winter 1944, D. Bakradze mentioned the leaflets Nazis posted in the villages (1961),

Hereby we inform the population: anyone who capture a Jew and bring $\mathrm{him} / \mathrm{her}$ to our headquarters would get a kilo of salt for each Jew. Organize a Jew hunt, it does not matter whether it is a female, a male, a child or an elderly person, catch them and bring them to $u s^{102}$.

In Igor Chernyiy's book «Dannyie dostovernyi» («The Data are Reliable») Jews were just mentioned twice along with the other categories of Nazis' victims: «mass arrests of the former Communist Party and Soviet

\footnotetext{
${ }^{101}$ Бакрадзе, Карпатский рейд, 10.

${ }_{102}$ Бакрадзе, Кровью героев, 291.
}

activists, prisoners of war who escaped from the camps, and Jews» ${ }^{103}$. Then he mentioned «massacre of civilians, senseless killings of women, children and elderlies, mass extermination of Jewish population» ${ }^{104}$. This very allusion is noteworthy because when mentioning «civilians», the traditional formula that was usually used to camouflage Jewish victims, the Jews, however, were singled out in a separate category.

In Nikolay Moskvin's reminiscences (1971) the scene of Jews extermination was just a background for the story about Trofim Zaharov's escape. A captured Soviet scout was brought for execution together with a group of people of various ages, and only the allusion to a gray-haired old Jew praying before the execution pointed out to the readers that it was not just killing of «the Soviet civilians» ${ }^{105}$.

The memoirs (1959, 1961, and 1964) by Vladimir Lobanok, a partisan commander and Secretary of the Lepiel District Committee of the Belorussian Communist Party, described certain events in Vitebsk, where «a camp for civilians was organized, and where they starved out and were shot», and «a huge territory around metalworkers' club was turned into Jewish ghetto». Referring to the eye-witnesses' stories the author of the book described in the next three paragraphs «the technology» of civilians killing by Nazi: naked elderlies, women, and children shot down at the edge of the dungeon. There is no doubt that the executed people were Jews, but in the text they were presented as just the «Soviet citizens»"

Grigoriy Linkov, a commander of the $1^{\text {st }}$ Belorussian Special Operations Unit, in his memoirs (the second edition 1951, 1953, 1956, 1959, 1960, 1961, and 1962) mentioned without any «camouflage» execution of the Jews in different cities and villages of the Vitebsk region. A separate episode was devoted to the extermination of the Jews from the village of Lukoml. The very reason for killing of 150 families was accusation of the Jews in killing of a German officer and an interpreter. At the same time, it was mentioned that «the Jewish population was shot by Hitlerites for no reason». G. Linkov also wrote that «as a rule Hitlerites made policemen shoot people. They just showed the policemen how to do it». The readers were informed that in the city of Krasnoluki Nazis turned the shooting of the Jews into a kind of initiation procedure for newly recruited policemen. Besides,

\footnotetext{
${ }_{103}$ Игорь Черный, Данные достоверны (Москва: Воениздат, 1968), 65.

104 Черный, Данные достоверны, 193.

${ }^{105}$ Москвин, Партизанскими тропами, 198-199.

${ }^{106}$ Владимир Лобанок, В боях за Родину (Минск: Беларусь, 1964), 25-26.
} 
people's blood on the hands of the new policemen left them no chance of going back ${ }^{107}$.

Dmitriy Medvedev in his book «Eto byilo pod Rovno» («It was near Rivne») (1948, 1949 (3), 1950 (3), 1951, 1956, 1957, 1958, 1961, 1962, 1968, 1981, 1982, and 1985 (2)) told us about the anti-Jewish component of the «New Order» in details,

When fascists occupied cities and willages of Western Ukraine, they announced registration of the Jews. They took away their property and sent them to work in rock quarries.

At the end of August, exactly as planned, Jewish population was «liquidated» in Rivne and other districts close-by. Hitlerites took huge groups of the Jews outside the city, made them dig graves for themselves, then they shot the Jews and without examining who was alive and who was not, pushed the bodies down into the graves and buried them.

These ogres had mercy to no one: neither to elderly, nor to babies.

Only few managed to escape. And it did not mean they saved their lives.

Under threat of execution the Germans forbade the locals to help the Jews. They posted announcements about rewards for betrayers: one kilo of salt for each betrayed $\mathrm{Jew}^{108}$.

In another book of this author - «Silnyie duhom» («Strong in Spirit») (1950, 1951 (2), 1952, 1953, 1955, 1957, 1958, 1959 (2), 1960, 1963, 1964, 1965, 1967, 1968, 1969, 1971, 1972, 1975, 1978, 1979, 1980, 1981, 1984 (2), and $1985(3))^{109}$, that, in fact, was an enlarged and redrafted edition of the previous book ${ }^{110}$, this very episode was omitted. But both book included the story of a Jewish boy named Pinya who was found by partisans in the woods, and who miraculously survived the executions"'.

In Ilya Davyidov's book (1973) the destiny of the Jews from Chocimsk was described in one paragraph. The episode was presented as a story of a girl who was found by partisans in the wood after her escape during execution

\footnotetext{
107 Григорий Линьков, Война в тылу врага (Саранск: Мордовское книжное издательство, 1960), http://militera.lib.ru/memo/russian/linkov_gm01/linkov_gm01.html.

108 Дмитрий Медведев, Это было под Ровно (Москва: Детская литература, 1968), http://lib.ru/ MEMUARY/.../MEDWEDEW/rovno.txt.

109 In Albert Tsessarskiy's foreword it was mentioned that from the moment the first edition of the book was released «it was re-published more than 50 times just in the USSR alone». See: Дмитрий Медведев, Сильные духом (Москва: Правда, 1985), 5. Most likely the translations are also included.

110 In the imprint this text often is attributed to fiction, though the memoir nature of the major part of it is obvious.
}

111 Медведев, Это было под Ровно; Медведев, Сильные духом, 78. of ghetto dwellers ${ }^{112}$. Anton Brinskiy mentioned mass killings of the Jews in various Volhynian villages ${ }^{113}$. Petr Ignatov's «Zapiski partizana» («Partisan's Notes») (1947, 1948, 1949, 1959, 1963, and 1973) included three pages with story about Krasnodar Jews registration by Nazis, a registration that turned into Jews extermination ${ }^{114}$. Memoirs by Mihail Salay (1981 and 1985 ) included two paragraphs about shooting of the Jews from the villages of Korop and Koriukivka in the Chernihiv region. The author also mentioned that the Romas were killed when the Jews had been exterminated in Koriukivka"

Aleksey Fedorov, the First Secretary of the Chernihiv Underground Communist Party Regional Committee, presented Holocaust through the stories about the life of Yakov Zusserman, his friend (1949 (book 1), 1952 (book 1-2), 1954, 1955, 1961, 1975, and 1985 (book 1-3)). He was surrounded and was breaking out to his home city Nizhyn. A. Fedorov talked his fellow escapee out, "Yakov, do not go to Nizhyn. Yes, I know, you have your wife there, you have your children there, but what can you do for them being all alone? They will catch you and drag you to Gestapo. From the look of yours it is clear that you are a Jew» ${ }^{116}$. However, these arguments did not persuade the soldier who was worried about his family. Later on he managed to send Fedorov a letter telling him a story about Gestapo organization in his city and about execution of his family ${ }^{117}$. The second part of the book contained a quite detailed story about Yakov's wandering: he came to Koriukivka hoping to find his family at his friends'. There the personnel of the local hospital hid him in the morgue from Nazis. At night Yakov helped members of the local underground organization to write leaflets and tried to persuade the local Jews from registration and make them leave the city. When 300 Jews were shot along with one of the female members of the underground organization Yakov left the city ${ }^{11}$.

The stories about destiny of the Jews who happened to be on the occupied territories indicate the author's expectation that the readers have some background knowledge about Nazis' attitude to the Jews the same way

\footnotetext{
${ }^{112}$ Давыдов, Юность уходит в бой, 214-215.

${ }^{113}$ Антон Бринский, По ту сторону фронта (Горький: Волго-Вятское книжное издательство, 1966), https://royallib.com/book/brinskiy_anton/po_tu_storonu_fronta.html.

114 Пётр Игнатов, Записки партизана (Москва: Московский рабочий, 1973), 307-309.

115 Михайл Салай, По знакомым дорогам : записки старого партизана (Москва: ДОСААФ, 1981), $28,58-59$.

${ }^{116}$ Алексей Федоров, Подпольный обком действует (Москва: Советский писатель, 1949), 55.

117 Федоров, Подпольный обком действует, 164.

118 Федоров, Подпольный обком действует, 319-323.
} 
as it was in the situation with prisoners of war. It is clear from the mentioned above episode with A. Fedorov's remark addressed to Y. Zusserman having no explanation about special risk for a Jew. In the memoirs (1959, 1961, and 1971) by Stanislav Vaupshasov, a professional diversionist and a commander of the partisan unit that was fighting Nazis at the territory of Belarus, the same way described was an episode about a guy who was caught by the partisan reconnaissance group while he was trying to escape when he met the armed people in April 1942. The detainee explained that he took partisans for German soldiers or policemen, «They shot my father, sisters, and now they are trying to catch me». He showed partisans his Young Communist League card and the questioned peasants verified the detainee identity - he was a member of the Young Communist League, Dolik Sorin". The Jewish descent of Sorin was openly mentioned much further in the book ${ }^{120}$.

A quite detailed description of Holocaust in Rivne was given in memoirs (1966 and 1975) by Terentiy Novak, a head of the city underground organization. The allusions to persecution of Jews were scattered over the text as one of the elements of the «New Order» description: execution of the groups of Jews at the streets, in prison, slip of the tongue of the police chief about preparation for extermination of the whole Jewish population of the city and a story about ghetto prisoners - workers of the coffee factory ${ }^{121}$. The author of the book described in details the story of ghetto extermination devoting two parts of the chapter «Stolitsa Ukrainyi» («Capital of Ukraine») to it. There was no description of how the life was organized in ghetto. On four pages Novak told the readers how the members of the underground organization, including him, tried to warn ghetto dwellers about the coming «action». Majority of those who they talked with could not believe that the German authority were so brutal ${ }^{122}$. Novak as a witness describes the «action» itself on three pages: he almost got inside the police line trying to get to ghetto for yet another try to warn its population about coming catastrophe. The author told the story how the Nazis started gathering the Jews, then how he observed columns moving outside the city through the window of his friend's place. People were brought to Sosenki

\footnotetext{
${ }^{119}$ Станислав Ваупшасов, Партизанская хроника (Минск: Беларусь, 1971), 26.

${ }^{120}$ Ваупшасов, Партизанская хроника, 397.

${ }^{121}$ Терентий Новак, Пароль знают немногие (Москва: Воениздат, 1966), 39, 63, 92-93.

122 Новак, Пароль знают немногие, 112-115.
}

where that very day «till the evening submachine guns did not stop rattling even for a minute as well as muffled rumble of machine-guns»" ${ }^{123}$.

Holocaust was described in details in the reminiscences of Resistance members in the Crimea. In Ilya Vergasov's «Kryimskie tetradi» («The Crimean Diaries») (1982) it was told about imposing a million worth contribution on Yalta Jewish community. Just one sentence was used to mention ghetto organization and quite in details described was its dwellers persecution. The racial approach of the Nazis was emphasized - members of the mixed families of Russian ethnicity were allowed to leave, but the children of Jewish appearance had to stay among doomed to be killed ${ }^{124}$.

In more details Holocaust in Kerch was described in Ivan Kozlov's book «V kryimskom podpolie» («In the Crimean Underground») (1947 (2), 1948 (7), 1949 (2), 1952 (2), 1954, 1956, 1958, 1960, and 1972). When the author of the book made the decision to stay in the underground organization, he said to his wife, «You are Jewish, so you cannot stay with me» ${ }^{125}$. An episode about Polya Govardovskaya, a member of the Young Communist League, is a kind of funny one. Kozlov did not want to leave her in the underground organization because of her Jewish origin. Such refusal with «ethnic-based rationale» the girl took as a kind of discriminating one,

She was so offended when I mentioned this reason!

"I was born and raised in the Soviet Union and I have never seen any difference between a Jew and a Russian. And now when our Motherland needs to be protected, you remind me about it...»

I told her that Germans are particularly brutal with Jews ${ }^{126}$.

P. Govardovskaya managed to have it in her way, and she stayed in the underground unit with the documents verifying her Armenian ethnicity.

When Kozlov was describing occupation, he mentioned an episode about registration of entire Jewish population ${ }^{127}$ in Gestapo and gave serious consideration to what happened on November 29, 1941, when all Jews had to arrive to Sennaya Square to be «evacuated». He failed persuading Govardovskaya's mother not to go there and to find shelter. The woman did not believe that mass killings were possible. The Jews were taken somewhere and an old man who was late was killed at the spot. In couple of days people

\footnotetext{
${ }^{123}$ Новак, Пароль знают немногие, 115-118.

${ }_{124}$ Илья Вергасов, Избранное (Крымские тетради) (Москва: Советский писатель, 1982), 31, 45, 48-49.

${ }^{125}$ Иван Козлов, В крымском подполье : воспоминания (Москва: Молодая гвардия, 1948), 19.

${ }^{126}$ Козлов, В крымском подполье, 32.

${ }^{127}$ Козлов, В крымском подполье, 52.
} 
in the city found out about regular executions in Bagerovskiy ditch ${ }^{128}$. Few pages in the book were devoted to the episode the author of the book witnessed: a woman jumped out of the truck that was transporting the arrested Jews. The truck stopped and one of the guards tried to bring the desperately resisting woman back to the truck, but he was surrendered by the crowd of the locals.

All of a sudden an old woman fell down between the arrested Jewish woman and the policeman. Some people rushed to help her up and pushed the policeman away. At this moment a boy jumped out of the car and disappeared in the ruins of some buildings.

The guard in the truck started shouting. The policeman left his victim alone 'cause he was afraid that the rest of the arrested people could escape, cursed out, jumped into the truck and they left'.

The rescued Jewess was taken by one of the local women ${ }^{\text {so }}$.

Kozlov also mentioned Krymchaks. Their registration, announced after extermination of the Jews, became the reason for rumors about planned extermination of the Russians (very much in the same vein as the Kiev saying mentioned by Anatoliy Kuznetsov) $)^{\text {s' }}$,

When Gestapo was registering Krymchaks, the city was full of rumors that Germans are going to kill Krymchaks. «Yesterday they shot Jews, tomorrow they will kill Krymchaks, and the day after tomorrow they will come for Russians», discussed the workers ${ }^{12}$.

In the context of the story about Lida Trofimenko, a member of the Simferopol underground organization, mentioned was Holocaust in this city. The girl was trying to help her Jewish friend who was brought to ghetto ${ }^{133}$.

Looks like the story of Minsk ghetto was described much better than the others in the war memoirs. Just one sentence was used to mention the fact of Minsk ghetto organization in Roman Machulskiy's notes (1965, 1969, and 1978), «The Hitlerites fenced the territory around Yubeleynaya square and Jewish cemetery and arranged ghetto where dozens of people were dying every day» ${ }^{134}$. Just few more details about Minsk ghetto were giv-

\footnotetext{
${ }_{128}$ Козлов, В крымском подполье, 55-57.

${ }^{129}$ Козлов, В крымском подполье, 58.

${ }^{130}$ Козлов, В крымском подполье, 58-59.

${ }^{131}$ Germans came - it is so good! Brought to all the Jews kaput. Gypsies will also be gone. And Ukrainians later on.

${ }_{132}$ Козлов, В крымском подполье, 61.

${ }^{133}$ Козлов, В крымском подполье, 150-151.

${ }_{134}$ Роман Мачульский, Вечный огонь : партизанские записки, 3-е изд., доп. и испр. (Минск: Беларусь, 1978), 35.
}

en in memoirs $(1952,1959,1970$, and 1973) by Vasiliy Kozlov, the First Secretary of the Minsk Underground Belorussian Communist Party Regional Committee and a commander of Minsk partisan unit, and the Chairman of the Presidium of the Supreme Soviet of the Belorussian SSR in 19481967. Ghetto was mentioned in the story of the witness of Nazi crimes in the occupied city,

Huge territory around Yubeleynaya square and Jewish cemetery the Hitlerites fenced as a ghetto. There is no Yubeleynaya square in Minsk any more, now we have «Sklaven-platz» named this way by Hitlerites, «Square of Slaves». Here hundreds of the Jews are dying every day tortured by fascists. Jewish cemetery is covered by dead bodies. Scraps of yellow cloth are sewed on the clothes of Jews ${ }^{135}$.

Much more detailed story about Minsk ghetto we can find in cited above book «Partizanskaya hronika» («Partisans’ Chronicles») by Stanislav Vaupshasov $(1959,1961$, and 1971). The episode was presented as a story of a liaison of the local underground organization who came from Minsk. She told partisans about horrors of Nazi occupational regime and that «Minsk ghetto is a real hell, each stone there is soaked in tears and blood of the Soviet people. What for? Just for being Jews» ${ }^{136}$. Further two pages were devoted to detailed story of what happened to its dwellers. In particular, described were shootings that happened on November 7, 1941, that resulted in the death of 15,000 people. In details described was an «action» carried out on July $28,1942$.

On 27 of July, fascist monsters ordered their servants - policemen to post announcements in every district of the ghetto informing people that on 28 of July all the ghetto dwellers of 15 years old and elder shall come to Yubeleynaya square by 9 a.m. Usually in this square located in the center of Minsk ghetto, the ghetto dwellers received distinguishing arm-bands: red ones for those who worked and green ones for unemployed. The announcements warned that for disobeying the order the people in fault would be shot ${ }^{137}$.

Those, who could, left the ghetto with columns of workers. The rest of the people were made come to the square. There the Nazi management

135 Василий Козлов, Люди особого склада (Москва: Молодая Гвардия, 1952), 122. Repeated in 1959 edition. The same episode with some changes in style was also used in V. Kozlov's book «Veren do kontsa» («Loyal to the End») (Moscow: Politizdat, 1970 and 1973. The second edition reached 200,000 copies).

${ }^{136}$ Ваупшасов, Партизанская хроника, 215.

${ }^{137}$ Ваупшасов, Партизанская хроника, 215. 
of ghetto were sitting at the desk. Composer Ioffe was made deliver a calming speech from the tribune placed next to the desk, and at the end of the speech

...from every corner several dozens of covered black cars - mobile gas chambers - entered the square. Ioffe immediately understood what happened. And people understood it as well. The composer raised his fists and shouted to the worried crowd where the word «gas chambers» spread like a lightning.

«Comrades! I deceived you, they are going to kill you! Damned butchers...»

Ioffe's last words drowned by the scream of thousands of people that went mad and run into different direction in fear. Everything turned into the huge maelstrom of human beings.

Fascists dragged Ioffe from the tribune and brutally murdered him. Fascists that sealed off the square started shooting with machine-guns those who tried to escape.

When they killed several hundreds of people covering the square and adjacent streets with dead bodies, they managed to «restore the order».

They arranged endless lines of women and elderly to the dozens of gas chambers. Nazis separated children from grown-ups and made them kneel.

They had to stay like that till their last moment of life $e^{13}$.

Then described were killings and pogroms that lasted for further several days in ghetto ${ }^{13}$.

Most detailed the destiny of Minsk ghetto dwellers was described in «Zapiski aktera i partizana» («Notes of the Actor and Partisan») by Nikolay Schensnovich (1976). In these memoirs the story of the author about his underground activity was accompanied by detailed description of the «New order» in the city and the way the locals managed to adapt themselves to it. Separate chapters were devoted to Nazis’ anti-Jewish policy: «V getto» («In the Ghetto»), «Tretiy i chetvertyiy pogromyi» («The Third and the Forth Pogroms»), and «Konets getto» («The End of Ghetto»). This policy was also mentioned in other parts of the book. The author specifically underlined that in his book he touched upon just «main phases of this horrible story I witnessed personally or wrote based on the stories of other witnesses who lived in ghetto and experienced its terror»"${ }^{\text {Ho }}$. Indeed, the story included so many details that were known to the witness in contrast to the majority

\footnotetext{
${ }_{138}$ Ваупшасов, Партизанская хроника, 216.

${ }^{139}$ Ваупшасов, Партизанская хроника, 216-217.

140 Николай Сченснович, Записки актера и партизана (Минск: Беларусь, 1976), http://militera.lib. ru/memo/russian/schensnovich_ni/01.html.
}

of other memoirs that reproduced the «polished» narration of someone's information.

The author depicted not only the Nazi terror, but the ghetto's everyday life. In particular, in the section «V getto» («In the Ghetto») described were the process of its organization, relocation of the people and conditions of their accommodation, Judenrat organization and operation. At that Schensnovich did not stick to the tradition of presenting just facts of fascist violence and unambiguous disapproval of collaboration with invaders. In particular, while describing Judenrat «election» (that happened in the German commandants office by means of candidates beating and their further interviewing), the author mentioned the efforts of Judenrat head aimed at easing the life of those under his wardship.

The Judenrat was headed by Ilya Efimovich Mushkin, who played a quite honorable role in the gloomy history of Minsk ghetto... He took his role of the Chairman quite seriously. He was quite energetic and soon two hospitals, an orphanage and a nursing home, two drug-stores and bakery were opened there. Disinfection chamber and sanitary department were operating there closely monitoring and maintaining the sanitary state of the living quarters and the entire territory ${ }^{14}$.

Positive remarks were made about the activity of Ruditser, a head of the Judenrat's Department of Labor, who tried to ease the living conditions for ghetto dwellers to the maximum when the forced labor was introduced. Creation of the Judenrat police was also described in the memoirs, and it was mentioned that

Minsk Town Council had the department dealing with ghetto issues and they allocated certain amount of money and some flour for the Jewish committee. The amount of rationed bread was not enough even for halfstarving existence. The canteen was able to give food to the minimum number of hungry people ${ }^{142}$.

The description of «normal life» was followed by the story about the Nazi terror against ghetto dwellers. The Nazi started with manhunts at the ghetto streets. After manhunts the motor vehicles, where the captured ones were brought to, returned back just with their belongings. In response the ghetto dwellers started to arrange various shelters and hidings.

Schensnovich described in details the «pogrom» that happened on November 7, 1941. While in the book by Stanislav Vaupshasov the fact of killing of 15,000 people as the result of it was just stated, Schensnovich described the entire procedure. One of the ghetto districts was sealed off and

\footnotetext{
${ }_{141}$ Сченснович, Записки актера и партизана.
}

${ }_{142}$ Сченснович, Записки актера и партизана. 
its population was moved away and shot down within three days. «Sonderghetto» was organized in the «freed» streets where the Jews from Frankfurt, Hamburg and Czechia were brought. The first pogrom was followed by the second one on November 20. Schensnovich mentioned the number of victims referring to the data received from a member of Judenrat: twenty thousand on November 7 and eight thousand on November 20.

The chapter «Tretiy i chetvertyiy pogromyi» («The Third and the Forth Pogroms») was devoted to the «actions» that happened on March 2 and July 28,1942 , and description of the Nazi crimes in between them. The description of July pogrom was less vivid and emotional than that of Vaupshasov's, but it included more «technical details». The section «Konets getto» («The End of Ghetto») was about Nazi «action» of 1943 - systematic step-by-step killing of patients and medical personnel, manhunts and shootings. The author almost without any emotions registered the Nazi crimes describing their «technology» as well as various ways of saving ghetto prisoners. Two stories of the people who managed to escape from ghetto were told.

Schensnovich mentioned that people who managed to escape from ghetto tried to get to partisans. The story about these people made up the second «Jewish unit» of the book consisting of three sections «Partizanskiy byitkombinat» («Partisan Consumer Service»), «Tunnel» and «V «dushegubke»» («In the Gas Van»).

The memoirist when describing the partisan period of his biography mentioned his visit to Kalinin partisan unit being

the major Jewish family camp. To protect people staying in it, a group of around 100 armed people was arranged, and this group was called Kalinin partisan unit. The entire family camp had the same name. [...] In 1943 Kalinin camp grew and reached the size of a town. More than 700 people stayed there, and later the number of its inhabitants reached almost 1000 people $e^{143}$.

Owing to huge number of doctors and medical personnel the camp, in fact, functioned as the partisan medical center, «Two hospitals were opened there with doctors, medical attendants and nurses who fled from Minsk and other cities, and outpatient clinic receiving patients constantly». Other camp inhabitants also were working as per their trade providing partisans and dwellers of the territories under their control with various handcraft products.

People from various cities and towns stayed there: Warsaw, Lódź, Kraków, and Białystok, but majority of them were from the Baranovichy region. Every one of them lost someone from his or her family, and some

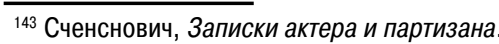

of them lost the entire family. There were wives whose husbands were tortured to death by Nazis, mothers moaning their children who were killed in front of their eyes, men who witness the shooting of their wives and children $^{144}$.

The memoirist wrote about the silence that reigned in the premises where the craftsmen worked in ghetto, «Then I understood that they were working with all their might trying to suppress their memories so awful that gave them no break neither in the light of the day, not at night». The stories of these people were quite similar having some difference in details,

But all of them were similar. The Germans were not creative and taunted people in one and the same way, hence, it was not just cruelty of individuals, it was a preliminary developed plan and they were following it precisely and carefully ${ }^{145}$.

However, the writer devoted separate chapters to two stories. «Tunnel» included a story of Leyba Pinchuck about mass escape from Novogrud ghetto through tunnel dug under the fence. The chapter «V «dushegubke»» («In the Gas Van») was about Sonia Grinberg from Baranovichy. She had to sort out the belongings of the perished people and clean «Gaswagen» after each run. For some kind of mistake the girl was beaten up and enclosed in one of such motor vehicles. She managed to escape by sheer luck: the door of the cabin was not closed tight and she with some other «passengers» managed to leave the vehicle en route.

I have already mentioned reminiscences about the Soviet Resistance activities aimed at saving Jews. In some memoirs such stories occupied a separate place. Thus, the mentioned above Vladimir Lobanok's memoirs (1959, 1961, and 1964) included a story about operation of the underground group of the employees of Polotsk orphanage, «one of the main goals of «Besstrashnyie» («Fearless») group was rescuing children. Nine children of Jewish origin were in great danger». Some of them found shelter in the villages, the others were sent to partisans with time ${ }^{146}$.

Holocaust in Babruysk was described in Vladimir Yakovenko's book,

Hitler's butchers were especially cruel and brutal with Jews. Even the slightest suspicion about racial «inferiority» was enough to force hundreds and thousands of the Soviet citizens into the special camps where they suffered one and the same awful fate: painful death after endless tortures

\footnotetext{
${ }^{144}$ Сченснович, Записки актера и партизана.

${ }^{145}$ Сченснович, Записки актера и партизана.

146 Лобанок, В боях за Родину, 305-306.
} 
and humiliation. Babruysk underground members, especially women, did their best to save these people ${ }^{147}$.

One of them, Mariya Masyuk, offered shelter to Emma Wolfson, a girl of Jewish origin, though she knew that her life and the lives of her children were at risk in case the girl was found ${ }^{\text {us }}$. Another episode demonstrated that the punishment was inevitable: the arrested underground unit member shared the cell in SD dungeon with a woman who was brutally tortured for giving shelter to her friend of Jewish origin "'. . Once Wolfson was almost discovered by a drunken German Feldwebel who broke into the apartment. That very time the underground group members managed to eliminate the threat ${ }^{\text {sso }}$. Unfortunately, the girl died in a month: on November 5 , she and all inhabitants of the ghetto were shot by Nazis ${ }^{\text {s1 }}$. When describing the plundering of Jewish belonging that followed the shooting, the memoirist mentioned that

Just few days past and some specialized shops were opened in Babruysk where the Hitler's butchers who still had blood of their victims on their hands started selling the belongings they took off from the Soviet citizens they killed $^{\text {is. }}$.

After the «action» held on the fifth of November, «Babruysk underground committee gave an urgent instruction to the groups to start a campaign among the local inhabitants and call the Jewish population to flee to the woods under the protection of partisan units» ${ }^{135}$.

Mihail Prudnikov's presentation of the story about rescuing Jews in his memoirs is of interest. This plot is a part of story about the pre-partisan period of medical doctor Anna Savkova's life on the occupied territory. Once a policeman came to her place late at night and brought her to the village headman [starosta]. The village headman asked the doctor to keep secret: he sought for medical help for the Jewish family he sheltered. The doctor agreed to help, «for several weeks the village headman and his wife with the help of Anna Alekseevna [Savkova] nursed the exhausted people and finally put them on their legs. In winter and spring the Lekahs /the last name

\footnotetext{
148 Яковенко, Партизанки, 21.

149 Яковенко, Партизанки, 37.

150 Яковенко, Партизанки, 22-24.

151 Яковенко, Партизанки, 24-25.

152 Яковенко, Партизанки, 24.

153 Яковенко, Партизанки, 25.
}

$\overline{147}$ Владимир Яковенко, Партизанки (Москва: Воениздат, 1980), 21 of the Jewish family - by D. Sh.J were offered shelter by peasants and in summer they joined Myishko partisan unit»"s".

Shneyder, a former Warsaw tailor, was in Dmitriy Medvedev partisan unit. Some credit for his survival went to some enterprising German General, though he did not plan it at all,

When Polish capital was occupied by Hitlerites, the Jews were drove together in ghetto. Shneyder's relatives were shot and he managed to survive because a German General, presumably the city Commandant, took him into his apartment. He placed the tailor in a tiny room in the attic of his mansion and made Shneyder tailor not only for him, but for the other Nazi officers as well. The money for the products the General embezzled. But Shneyder thanked his lucky stars recalling with terror those who got into ghetto. Once the General told him that he was not going to keep him in his place anymore. There was the only way out from ghetto - to be shot. And Shneyder decided to flee. He managed to do it. After going through many trials, he joined our unit ${ }^{155}$.

The story of survival told in S. Vaupshasov's book is more unexpected. The memoirs were about May 1943. At that time a head of Minsk Antiaircraft Defense - an Oberst, and Hauptman Hans, a pilot, sided with partisans (the name of the Oberst was not mentioned). The Oberst met Elsa, his friend from Hamburg, in ghetto. When he received the information about coming slaughter of ghetto dwellers he decided to act finding a support in the person of a pilot who became disillusioned with Nazism. Together they moved Elsa, her sister and two children (whose children it was not specified) from ghetto using the official vehicle. They shot the driver who tried to escape when they approached the partisan controlled area. While staying with the partisans, the pilot took part in sabotage operations, and the Oberst was studying the Russian language. In few months they were moved to Moscow together with women and children ${ }^{156}$.

Memoirs described some separate attempts of the Jews to survive on the occupied territory. Above I mentioned some reminiscences about certain partisan units or family camps integrated into the partisan institutions.

Dmitriy Medvedev in his book «Silnyie duhom» («Strong in Spirit») described a meeting of Nikolay Kuznetsov, an intelligence officer, with a group of Jewish refugees. An explanation was given to the readers, «The groups of the people trying to escape from fascist quite often were hiding

\footnotetext{
${ }^{154}$ Михаил Прудников, Неуловимые (Москва: Воениздат, 1961), 139-140.

${ }^{155}$ Медведев, Сильные духом, 116-117; Медведев, Это было под Ровно.

${ }^{156}$ Ваупшасов, Партизанская хроника, 247-252.
} 
in the woods and when they met partisan units they join such units, the way it happened in our Tsuman' and Sarny woods» ${ }^{157}$.

Several memoirists, the former partisans of Kovpak unit, described their meeting with the Jews who escaped from Stanisławów ghetto. On their way back from the Carpathian Raid in the summer 1943, the partisan reconnaissance squad spotted a camp of 300 Jews who found shelter in the Black Forest (Chernyiy Les) (woodland in the territory of the Ivano-Frankivsk region). David Bakradze (1961 and 1968) described the meeting with the camp dwellers. They were unarmed and hoped to survive staying in the woods. Partisans of Kovpak unit gave them some arms to protect themselves, while some Jews including the camp supervisor, medical doctor Tsimmer, joined the Soviet partisans ${ }^{158}$.

The memoirs by Ivan Berezhnoy, an intelligence officer of Kovpak unit, (1967 and 1976) did not include a separate story about the Jewish camp. The author focused on the story of one Jew, medic Miroslav Zima (in his memoirs this name was given to doctor Tsimmer. Probably the doctor took this name after the war when he started working in Czechoslovakia), who was met by the partisans in the Black Forest,

The war started when he lived in Stanisławow. The fascists registered all Jews and organized ghetto. Zima decided to flee. With the last bit of his money he bought a revolver and wanted to make product stock, but did not get a chance. He found out that Hitlerites wanted to shoot all Jews. Zima with some other families fled. He was hiding in the Black Forest for quite a long time. He was in touch with city dwellers and received medications from them and treated the patients ${ }^{159}$.

In Pyotr Vershigora's memoirs (1950, 1951, 1952, 1953 (2), 1955 , 1959, 1963, 1972, 1975, 1980, 1982, 1983, and 1985 (2)) the Jewish origin of the medical doctor was mentioned, however, the readers can figure out that he was one of the leaders of the Jewish camp only from the context. Prior to this episode about interaction with the doctor, Vershigora wrote that «we, by chance, heard from the battalion scouts, that the last survivors of Stanisławów ghetto were hiding somewhere in the very depth of the Black Forest. There were around a hundred people there - what remained from eighty five thousand Jews of the Stanisławów region brought behind the barbed wire» ${ }^{160}$.

\footnotetext{
${ }^{157}$ Медведев, Сильные духом, 485.

${ }^{158}$ Бакрадзе, Кровью героев, 124-126; Бакрадзе, Карпатский рейд, 116-117.

${ }^{159}$ Бережной, Два рейда, 331.

${ }^{160}$ Пётр Вершигора, Люди с чистой совестью. Кн. 2: Карпатский рейд (Москва: Московский рабочий, 1950), 310-313.
}

Another «Jewish episode» found in Vershigora's book was not included into the memoirs of the majority of his brother-soldiers. When describing fighting in the Carpathians, Vershigora mentioned that in Skalat one of the companies freed local ghetto prisoners - around 300 craftsmen and members of their families. For partisans these people, mainly women, children and elderlies, were a burden. So Kovpak offered to all combat-ready people to join his unit, the rest were promised some help in finding shelter,

Those who can and willing to carry the gun can stay. Those who hate fascists can stay! Those who do not afraid of being killed and ready to die for our Motherland can stay! Those who cannot or are not willing to do so - do not come with us, I speak straight out - do not come with us! We will help those who stay - will send you to the villages, people there will help you with shelter. And we will give you some food to take ${ }^{161}$.

Semen Tutuchenko, a cavalryman of Kovpak partisan unit, also wrote about freeing the Jews of Skalat. Though he did not mentioned any ghetto and did not inform about further destiny of the freed people,

The prison in Skalat was packed with Jews: two hundred people sentenced to death were freed by partisans. But 15 thousand have been already executed. We were too late to help them ${ }^{162}$.

Almost the same way described was an interaction with the Jews finding shelter in the woods in the memoirs by Grigoriy Linkov, who fought in Belarus

People cooped up in huts and dugouts built in a slapdash manner, shabby and starving: there were pregnant women, elderlies and kids. All of them spilled out to meet us. They did not know that we could not save them and were hoping for some kind of miracle. Though it was difficult to do, but I told them the truth: we were just a small mobile unit and the families cannot follow us. I promised to send the starving people some bread and meat and suggested them to go deeper in the woods for winter. I could take only those people who was able to carry a gun and ready to give their lives for our country. Some men jointed our group ${ }^{163}$.

This camp soon was devastated by German troops. A Jewish partisan unit was incidentally mentioned in the book, «burdened with their families», that was almost completely defeated by hit squads in August 1942.

In Linkov's memoirs there is a separate chapter, «Shpionki» («LadiesSpies»), telling the story about two refugees from Minsk ghetto that nearly

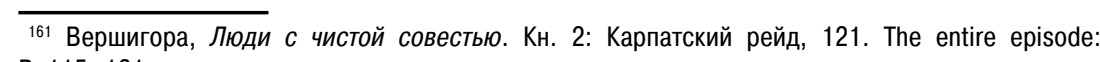
P. $115-121$.

${ }^{162}$ Семён Тутученко, Лесные всадники (Киев: Политиздат Украины, 1977), 34.

163 Линьков, Война в тылу врага. 
ended up tragically. The women came to the partisan unit with documents of a Pole and a Russian, but during questioning they gave confusing information. Linkov suspecting them of being Nazi collaborators was ready to give an order to shoot them, but at the last moment one of them confessed that both of them were Jews and their stories were fake because they came with fake documents. The system of proving their origin was quite interesting,

"And how can you prove your Jewish origin?»

«You have three Jews here and if you allow me talking to them they will verify our origin».

...In few minutes all three Jews confirmed that both women, who fled to the woods from Minsk ghetto, were indeed of Jewish origin ${ }^{164}$.

However, these proofs did not eliminate all the doubts: «we had to start verifying their identity in ghetto indirectly and at the same time checking them thought combat activity».

Another chapter of the Linkov’s book «Voyna v tyilu vraga» («War in the Enemy Rear») named «Mina Avraama Girshelda» («Avraam Girsheld's Mine») told the story how a defect in partisan mines was detected. Avraam Girsheld, a watchmaker, placed into the Slonim Labor Camp was offered collaboration by Nazis - he and his family were offered freedom for defusing the Soviet anti-removal mines. The watchmaker managed to find a drawback in the wiring and he learned how to defuse these mines. But being condemned as a traitor by his friends and after finding out that his family had been killed, he exacted vengeance - when he extracted yet another mine, he asked the German sappers whom he was training to come closer and exploded the mine. A letter from Avraam was sent to partisans explaining the reasons for his behavior and description how to eliminate the defect in the mines ${ }^{165}$.

More space (and care) was given to the Jewish camps in Anton Brinskiy's memoirs (book 1 1954, 1956, 1961, and 1966) who was a commander of the partisan unit operating in Belarus and Volhynia. When the partisans were near the village of Svarytsevychi of the Rivne region they received the information that «four healthy and strong men were living in the woods after marrying refugee Jewish girls». They were doing nothing, «but considered themselves to be partisans and based on this believe they ate and drank at the expense of the locals». It looks like A. Brinskiy was especially annoyed by this fact because

\section{4 Линьков, Война в тылу врага.}

165 Линьков, Война в тылу врага. ..close to them in the same woods there were hiding many Jews who fled from ghettos of the nearby towns and cities to survive fascist massacre. Shabby, starving and filthy they were afraid to meet people. Hitler's «new order» out of all the rights seemed to grant them the only one - the right to die. They were chased like wild animals: for one killed Jew the authorities gave a pack of cigarettes as a reward ${ }^{166}$.

As a result, the «bridegrooms», who was taken by A. Brinskiy as deserters, were ordered to «organize in the woods a «camp for civilians» for the Jewish refugees» and to take care about catering and logistics. The young men succeeded at it.

One and a half page was devoted to a story about other Jewish refugees who were found by the partisans in the woods: it was an old man with his two daughters and two granddaughters. Exhausted and frozen up they were hiding in the woods after execution of the Manevychi ghetto dwellers. A. Brinskiy could not abandon these people,

I sent them to the camp accompanied by one of my soldiers. There they will be given some food, will take bath and get some clothes. They will survive. But it was just one family, and no one knows how many of such homeless and feral people who escaped from ghetto of the nearby cities and towns wanders around the wood! They also do not have any means of support, they do not know how to survive in the wood, they also need some help. We saw many people like this... ${ }^{167}$.

The mentioned above meeting occurred on the way to the camp of Kruk's (nickname of Nikolay Konischuk) partisan unit. In fact, the camp was the Jewish one, «we saw old people, women and children; most of them were Jews... Kruk saved these people when brought them to his camp: no matter what, but they had roof over their heads and food there». At that, the local partisans, 20 people on a hundred refugees, were, in fact, just guards; A. Brinskiy wanted to have an active unit. That's why they reformed the camp: deep in the forest they organized a separate camp for civilians where the wood was the main defense measure, while the partisans freed their hands for active operation. Further in the book it was mentioned that the Jews who joined Filyuk partisan unit also managed to survive.

Mihail Salay (1981) memoirs included an episode describing the partisan attack on town of Glebovo where two women with kids who stayed there asked the permission to join the unit. They tried to persuade the commander, who was not really happy with their request, telling him that «their lives and the lives of their children are at risk because one of them is a Jew

\footnotetext{
${ }_{166}$ Бринский, По ту сторону фронта.
}

${ }^{167}$ Бринский, По ту сторону фронта. 
and the other is a wife of the communist who was well-known before the war and now is in the army». There was no information what happened to them at the end ${ }^{168}$.

Thus, as we can see, the issue of Jews extermination by Nazis can not be considered as tabooed or hushed up in the memoirs of the Soviet Resistance members. The description of Nazi persecution of Jews was an integral part of the stories about everyday life on the occupied territories, that some times took the significant part of the texts. Besides the immediate documenting of what was happening - ghetto organization and mass executions - the memoirists described interaction of Resistance members with Jews. At that, along with the stories about the support, the partisans and underground organization members gave to Jews, the readers could find the stories in general demonstrating that the rescue of this very category of the people was not the priority for many partisan commanders.

\section{Nationalists' Antisemitism}

The issue of Jews extermination in the Soviet war memoirs also was one of the means of describing «crimes of the Ukrainian bourgeois nationalists» ${ }^{169}$. Without denying the participation of Ukrainian nationalists in Jewish population extermination ${ }^{170}$, I would like to stress the ideological nature of such reminiscences; some of the episodes described by the writers are in little consistency with facts known as of today regarding the history of nationalist underground organizations.

In the book «Lyudi s chistoy sovestyu» («People with Clear Conscience») Petr Vershigora described the crimes of the gang of the Ukrainian nationalists led by a «Sashko» and organized by Nazis. Their main activity was extermination of Volhynian Polish population. According to the author of the memoirs, Sashko, who started his career in Gestapo as an

\footnotetext{
${ }^{168}$ Салай, По знакомым дорогам, 103.

${ }^{169}$ In the memoirs they recollect antisemitism of the Ukrainian nationalists, but the story looks as «exclusively Ukrainian» because, among other things, the other nationalists, including Lithuanian, almost were not present in the memoirs at all.

170 See: Per Anders Rudling, «The OUN, the UPA and the Holocaust: a Study in the Manufacturing of Historical Myth's", The Carl Beck Papers in Russian and East European Studies, no. 2107 (2011); John-Paul Himka, «Former Ukrainian Policemen in the Ukrainian National Insurgency: Continuing the Holocaust outside German Service», in Lessons and legacies XII. New Directions in Holocaust Research and Education, ed. and Northwestern University Press Evanston, 2017), 141-163; John-Paul Himka, «The Lviv Pogrom of 1941 The Germans, Ukrainian Nationalists, and the Carnival Crowd", Canadian Slavonic Papers, no. 2-3-4 (2011): 209-243; Іван-Павло Химка і Тарас Курило, «Як ОУН ставилася до євреїв? Роздуми над книжкою Володимира В'ятровича», Україна модерна 13 (2): Війна переможців і переможених (2008): 252-267.
}

interpreter, managed to climb the career ladder owing to his cruelty with respect to the local population and extermination of Jews ${ }^{171}$. The same way described was the so-called «Chernyiy voron» («The Black Crow») who was a German saboteur in the beginning of the war and later was exterminating Poles as a partisan-nationalist, «He is German SS man... he killed all the Jews» ${ }^{172}$. Further, when he defined Banderites as loyal servants of Himmler, Vershigora characterized the nationalists as follows, «their limit is Schutzpolizei black uniform. Extermination of Jews and Poles, deportation of millions of Ukrainian boys and girls to Germany, tortures of communists and the Young Communist League members in Kyiv, Poltava, Rivne and Lviv, shootings of prisoners of war in the camps - it's all their doing» ${ }^{173}$. At that, the nationalists were presented just like mere agents of Nazis. Vershigora wrote about some Goncharenko, one of the UPA (Ukrainian Insurgent Army) commanders (I did not manage to associate him with any real person), that at the end of 1941 he «chased and shot the Soviet prisoners of war along the roads, flushed out from the woods the families of the Red Army officers - their wives and children - and killed hundreds of Jews» as per SS officers' orders ${ }^{174}$.

Aleksey Fedorov in his book «Poslednyaya zima» («The Last Winter») (1965, 1970, 1981, 1982, and 1985) mentioned an episode of Banderite agent catch, who managed to worm his way into a Soviet partisan unit Ivan Lukyanyuk nicknamed «Stalnoy» («Steely»). According to his biography given in the book, he was a member of OUN (Organization of Ukrainian Nationalists) since he was 15, and in 1941 he joined the police, and then he was transferred to Feldgendarmerie. While he was there, he took part in the «actions» in Volhynia. In spring 1943 he joined UPA. Fedorov described UPA ideology as the one that was very similar to that of Hitler, «Banderites killed a Pole for being a Pole, a Jew - for being a Jew». Besides, the Ukrainians who demonstrated the slightest loyalty to the Soviet regime were in danger ${ }^{175}$. The killings of Jews were mentioned by the author when he described the so-called UPA «Zolotaya rota» («Golden Company») allegedly selected group of thugs that Banderites

...favored, protected from any danger, and used mainly for the most murderous and terrorist operations. To quarter a peasant suspected

\footnotetext{
171 Пётр Вершигора, Люди с чистой совестью (Москва: Воениздат, 1947), 251.

${ }_{172}$ Вершигора, Люди с чистой совестью. Кн. 2: Карпатский рейд, 78.

${ }^{173}$ Вершигора, Люди с чистой совестью. Кн. 2: Карпатский рейд, 87.

174 Пётр Вершигора, Рейд на Сан и Вислу (Москва: Воениздат, 1960), 103-104.

${ }^{175}$ Алексей Федоров, Последняя зима (Москва: Воениздат, 1985), 226.
} 
in helping the partisans, to saw alive Soviet activist, to «chop» Polish farmhouse dwellers «for stew» [ustroit' na pol'skom khutore «kholodets»], to crush Jew's head with a club - in such kind of crimes «Zolotaya rota» members were great at ${ }^{176}$.

In his memoirs Anton Brinskiy described nationalists from «Polesskaya Sech» («Polissian Sich») in the same manner as Fedorov described UPA. Besides, «Bulbivtsi» (the name of Polissian Sich members) «carried out anti-Polish, anti-Russian and anti-Jewish agitation accompanied by massacres»"

However, in Terentiy Novak's memoirs that were no less ideologically charged with respect to Ukrainian nationalists, Jews extermination in 1941 was described as an operation that was not agreed with Nazis,

Banderites slaughtered around three dozens of Jewish families, take your pick - former shop owners and jewelry shop owners. And the valuables - gold, watches, bracelets, and rings - they appropriated. But Nazis could not bear that someone else creamed off. Gestapo got to know about stoled valuables. They will drag them out from Banderites together with their sinews, I am sure! ${ }^{13}$

Novak also wrote about a Robotnitskiy, a head of «Ukrainian police» in Volhynia. He followed the instructions of OUN leaders according to which «Russians, Poles, and Jews were shot down in ravines, woods and next to the graves dug in rush along the shores of the quiet Horyn River. Special courts comprising of former kulaks and followers of Petliura dealt with shady Ukrainians»" ${ }^{179}$.

In the memoirs (1960) by Nikolay Popel, a member of Military Council of the $1^{\text {st }}$ Guards Tank Army, a story about exposure of German agent, Sergey Hotsenko, was included. As the result of interrogation, it was found out that the treason was based on ideological reasons as well, «Germans respect Ukrainians... They exterminated Jews and will make Moskovites go»"

However, the persecution of Jews was also mentioned as one of the «achievements» of Russian collaborators. In particular, Roman Machulskiy mentioned in his memoirs that Andrey Blazhevich's «Druzhina» («Squad») «during summer and fall of $1942 \ldots$ according to Hitlerite

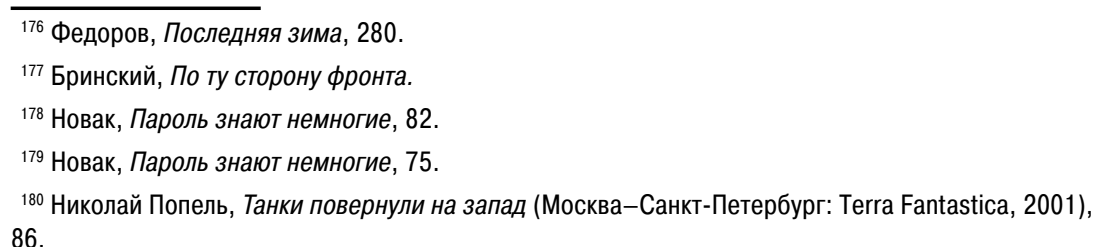

commanders' instructions was repressing partisans and organizing Jewish pogroms in the territory of Poland, in particular, in Lublin Voivodeship»" ${ }^{181}$.

As we see, in the certain ideological context the references to killings of Jews were intentionally instrumented by the Soviet memoirists, purposefully using them for demonstration of maleficent nature of Nazi collaborators.

\section{Conclusions}

The general trend of Holocaust issue hushing up in the Soviet public discourse is beyond doubt. However, the issue of (non)presentation of Jews mass extermination in the Soviet literature traditionally described by the researchers needs to be specified more precisely. If we step away from the customary focusing on the fiction only and address to the scope of the Soviet literature about «the Great Patriotic War» (including the fiction about the war), we will reveal a phenomenon presented in this article through the example of war memoirs. During the entire post-war period in the Soviet Union in parallel with Holocaust issue hushing up by authorities dozens of memoirs were published and republished openly describing killings of the Jews by Nazis during the war. The number of books published and republished as well as the positions occupied by some authors (top commanders, members of the CPSU Central Committee, and etc.) attest that we are dealing with not just ordinary oversights of the censorship. The publication dates of memoirs containing extensive descriptions of anti-Jewish policy hardly can be correlated with the traditional periodization of «Holocaust literature» - in the table you can see that such books went on publishing after 1948 and such texts were published and republished after the Khrushchev Thaw.

Another fact also draws our attention and requires additional thinking. These memoirs not only were published during certain period of time, but they were written during certain period of time as well. Thus, taking into account the traditional idea of univocal hushing up during the Soviet period, the «insensitivity» of the majority of the authors (including the high ranking ones) to the ideological situation of that days was surprising ${ }^{182}$. As we see, the memoirists believed it was allowed touching upon the issue of mass Jew

\footnotetext{
${ }^{181}$ Мачульский, Вечный огонь, 209. About this formation see: Дмитрий Жуков и Иван Ковтун, 1-я русская бригада СС «Дружина» (Москва: Вече, 2010), 87-88.

${ }^{182}$ I have to underline that it is true merely regarding Holocaust issue. But, for example, in memoirs published in 1945-1956 Stalin glorification was one of the repeated refrains, while in memoirs published
} starting from 1956 till mid 1960s the issue of mass repressions and personality cult was often included. 
extermination in their texts, though, no doubt, they had clear understanding the official ideological standpoint.

War memoirs in the climate of lack of Holocaust public commemoration were, no doubts, as an object of popular reading, one of the main channels of information about Nazi genocide against Jews for the Soviet society, especially of the post-war generations. In these books the reader could find the information about Nazis' ideological standpoint with respect to Jews (though a myth about «Judeo-Bolshevism»- «Żydokomuna» has never been mentioned), as well as how the «Final Solution» was implemented in the occupied territories. Besides, the issue of rescuing the Jews was covered - Jews rescuing without assistance or with the help of the Soviet Resistance and local dwellers. The authors put special focus on anti-Semitism and participation of Ukrainian nationalists in execution of the Jews, less interest was shown in collaborators. While the issue of anti-Semitism of locals was not covered at all.

According to reminiscences of war veterans, the memory about tragedy of Jews, though sometimes left untold, remained in the Soviet people's mind. It is evident from to not only the number of reminiscences, but their style as well - the authors wrote about Jews extermination in the way as if the readers knew about such doings from the very beginning.

Papers about politics of memory in the Soviet Union encourage me to make another conclusion. An attempt to use Western terminology to describe the Soviet environment results in perception distortion. When using term «Holocaust» (or «Shoah») we, one way or another, mean the description of a conceptualized phenomenon. When we apply it to the Soviet realia, we, at the end, get not just a substitute for «mass killings of the Jewish citizens» (or any other similar and the same way awkward construction used in the Soviet time texts), but also change the general notional ground of Jews tragedy understanding. In the Soviet time texts, in particular, in the war memoirs, the Nazi genocide against Jews was not singled out as a separate issue even in the works where extermination of Jews was described in details (for example, in Schensnovich's or Kagan's books). Jews were presented as a separate category of Nazi victims, anti-Jewish actions were described, but all of them were the part of Nazi «new order», one of the planes of population suffering in the occupied territories of the Soviet Union and Europe not a separate phenomenon. As a result, we actually face the Holocaust hushing up in the Soviet domain - but, at the same time, the memory about mass killing of the Soviet Jews was quite actively reflected in the war memoirs, though somehow limited.
The main conclusion that I propose is the necessity in reviewing and refining the traditional comprehension patterns of Holocaust issue presentation in the Soviet literature and in the public domain. As we can see through the example of war memoirs, we can not simplify to univocacy the hushing up position and have to comprehend the phenomenon of «non-nipped memory» in the semi-official texts.

Table 1. War memoirs containing detailed stories about genocide against Jews (prior to 1985) ) $^{133}$

\begin{tabular}{|l|l|c|c|}
\hline \multicolumn{1}{|c|}{ Book } & \multicolumn{1}{|c|}{ Publishing House } & $\begin{array}{c}\text { Year } \\
\text { of Publication }\end{array}$ & $\begin{array}{c}\text { Number } \\
\text { of Printed } \\
\text { Copies }\end{array}$ \\
\hline $\begin{array}{l}\text { D. I. Bakradze. } \\
\text { Karpatskii reyd }\end{array}$ & Moscow: Izdatelistvo DOSAAF & 1968 & 100000 \\
\hline $\begin{array}{l}\text { D. I. Bakradze. } \\
\text { Krovyu geroev }\end{array}$ & Tbilisi: Zaria Vostoka & 1956 & \\
\cline { 2 - 4 } $\begin{array}{l}\text { I. I. Berezhnoy. } \\
\text { Dva reyda: } \\
\text { vospominaniya } \\
\text { partizanskogo } \\
\text { komandira }\end{array}$ & Gorky: Volgo-Vyatka & 1961 & 50000 \\
\hline $\begin{array}{l}\text { V. I. Bondarets. } \\
\text { Voennoplenyie: } \\
\text { zapiski kapitana }\end{array}$ & Moscow: Molodaya Gvardiya & 1967 & 100000 \\
\hline \multirow{2}{*}{$\begin{array}{l}\text { A. P. Brinskiy. } \\
\text { Po tu storonu } \\
\text { fronta. Kn. 1. }\end{array}$} & Gorky: Gorky Publishing House & 1960 & 160000 \\
\cline { 2 - 4 } & Moscow: Voenizdat & 1956 & \\
\cline { 2 - 4 } & Gorky: Volgo-Vyatka & 1961 & \\
\hline $\begin{array}{l}\text { S. A. Vaupshasov. } \\
\text { Partizanskaya } \\
\text { hronika }\end{array}$ & Moscow: Voenizdat & 1966 & \\
\cline { 2 - 4 } $\begin{array}{l}\text { I. Vergasov. } \\
\text { Izbrannoe } \\
\text { (Kryimskie tetradi) }\end{array}$ & Minsk: Belarus & 1959 & \\
\cline { 2 - 4 } & Moscow: Sovetsky Pisatel & 1961 & 100000 \\
\hline
\end{tabular}

${ }^{183}$ Made up with the use of the electronic catalog of the Russian State Library, accessed January 18, 2019, https://www.rsl.ru/. 


\begin{tabular}{|c|c|c|c|}
\hline \multirow{15}{*}{$\begin{array}{l}\text { P. P. Vershigora. } \\
\text { Lyudi s chistoy } \\
\text { sovestyu. Kn. 2: } \\
\text { Karpatskiy reyd }\end{array}$} & Moscow: SovetskyRabochiy & 1950 & \\
\hline & Moscow: Sovetsky Pisatel & 1951 & \\
\hline & Moscow: Sovetsky Pisatel & 1952 & \\
\hline & $\begin{array}{l}\text { Moscow: State Literature } \\
\text { Publishing House (Goslitizdat) }\end{array}$ & 1953 & \\
\hline & $\begin{array}{l}\text { Sverdlovsk: Sverdlovsk } \\
\text { Publishing House }\end{array}$ & 1953 & \\
\hline & Moscow: Sovetsky Pisatel & 1955 & \\
\hline & Moscow: Sovetsky Pisatel & 1959 & \\
\hline & Moscow: Sovetskaya Rossia & 1963 & \\
\hline & $\begin{array}{l}\text { Barnaul: Altay } \\
\text { Publishing House }\end{array}$ & 1972 & \\
\hline & $\begin{array}{l}\text { Chișinău: Kartia } \\
\text { moldoveniaske }\end{array}$ & 1975 & \\
\hline & Moscow: Izdatelistvo DOSAAF & 1980 & \\
\hline & Kyiv: Politizdat Ukrainy & 1982 & \\
\hline & $\begin{array}{l}\text { Chișinău: Kartia } \\
\text { moldoveniaske }\end{array}$ & 1983 & \\
\hline & Kyiv: Politizdat Ukrainy & 1985 & \\
\hline & Moscow: Sovremennik & 1985 & \\
\hline \multirow{2}{*}{$\begin{array}{l}\text { I. Yu. Davyidov. } \\
\text { Yunost' uhodit } \\
\text { v boy }\end{array}$} & \multirow{2}{*}{ Moscow: Voenizdat } & 1965 & 65000 \\
\hline & & 1973 & 65000 \\
\hline \multirow{3}{*}{$\begin{array}{l}\text { D. A. Dragunskiy. } \\
\text { Godyi v brone }\end{array}$} & \multirow{3}{*}{ Moscow: Voenizdat } & 1973 & 100000 \\
\hline & & 1975 & \\
\hline & & 1983 & 100000 \\
\hline $\begin{array}{l}\text { I. L. Druyan. } \\
\text { Kliatvu sderzhali }\end{array}$ & Minsk: Belarus & 1975 & \\
\hline \multirow{6}{*}{$\begin{array}{l}\text { P. K. Ignatov. } \\
\text { Zapiski partizana. } \\
\text { Kn. 2: Podpolie } \\
\text { Krasnodara }\end{array}$} & Moscow: Molodaya Gvardiya & 1947 & \\
\hline & $\begin{array}{l}\text { Krasnodar: Krai } \\
\text { Publishing House }\end{array}$ & 1948 & \\
\hline & $\begin{array}{l}\text { Moscow: State Literature } \\
\text { Publishing House }\end{array}$ & 1949 & \\
\hline & Moscow: SovetskyRabochiy & 1959 & \\
\hline & Krasnodar: Publishing House & 1965 & \\
\hline & Moscow: SovetskyRabochiy & 1973 & 75000 \\
\hline $\begin{array}{l}\text { D. Z. Kagan. } \\
\text { Rasskazhi zhivyim }\end{array}$ & Ashgabat: Turkmenistan & 1980 & \\
\hline \multirow{2}{*}{$\begin{array}{l}\text { V. I. Kozlov. Veren } \\
\text { do kontsa }\end{array}$} & \multirow{2}{*}{ Moscow: Politizdat } & 1970 & \\
\hline & & 1973 & 200000 \\
\hline \multirow{2}{*}{$\begin{array}{l}\text { V. I. Kozlov. Lyudy } \\
\text { osobogo sklada }\end{array}$} & \multirow{2}{*}{ Moscow: Molodaya Gvardiya } & 1952 & \\
\hline & & 1959 & 75000 \\
\hline
\end{tabular}

\begin{tabular}{|c|c|c|c|}
\hline \multirow{18}{*}{$\begin{array}{l}\text { I. A. Kozlov. } \\
\text { V kryimskom } \\
\text { podpolie: } \\
\text { vospominaniya }\end{array}$} & Simferopol: Krymizdat & 1947 & \\
\hline & Moscow: Sovetsky Pisatel & 1947 & \\
\hline & Simferopol: Krymizdat & 1948 & \\
\hline & Moscow: Pravda & 1948 & \\
\hline & Moscow: Molodaya Gvardiya & 1948 & \\
\hline & Moscow: Molodaya Gvardiya & 1948 & 75000 \\
\hline & $\begin{array}{l}\text { Voronezh: Voronezh Region } \\
\text { Publishing House }\end{array}$ & 1948 & \\
\hline & $\begin{array}{l}\text { Riga: Latvian State } \\
\text { Publishing House }\end{array}$ & 1948 & \\
\hline & Kalinin: Proletarskaya Pravda & 1948 & \\
\hline & $\begin{array}{l}\text { Moscow: State Literature } \\
\text { Publishing House }\end{array}$ & 1949 & \\
\hline & $\begin{array}{l}\text { Saratov: Saratov Regionn } \\
\text { State Publishing House }\end{array}$ & 1949 & \\
\hline & Moscow: Sovetsky Pisatel & 1952 & \\
\hline & Simferopol: Krymizdat & 1952 & \\
\hline & $\begin{array}{l}\text { Moscow: State Literature } \\
\text { Publishing House }\end{array}$ & 1954 & \\
\hline & $\begin{array}{l}\text { Novosibirsk: Novosibirsk } \\
\text { Publishing House }\end{array}$ & 1956 & \\
\hline & Simferopol: Krymizdat & 1958 & \\
\hline & Moscow: Sovetsky Pisatel & 1960 & \\
\hline & $\begin{array}{l}\text { Moscow: Khudozhestvennaya } \\
\text { Literatura }\end{array}$ & 1972 & \\
\hline \multirow{2}{*}{$\begin{array}{l}\text { I. P. Krivonogov. } \\
\text { Rodina zovet: } \\
\text { zapiski ofitsera } \\
\text { sovetskoy armii }\end{array}$} & \multirow{2}{*}{ Gorky: Gorky Publishing House } & 1960 & \\
\hline & & 1963 & 75000 \\
\hline \multirow{7}{*}{$\begin{array}{l}\text { G. M. Linkov. } \\
\text { Voyna v tyilu vraga } \\
\text { (2nd version) }\end{array}$} & $\begin{array}{l}\text { Moscow: State Fiction } \\
\text { Literature Publishing House }\end{array}$ & 1951 & \\
\hline & Moscow: Sovetsky Pisatel & 1953 & \\
\hline & $\begin{array}{l}\text { Moscow: State Literature } \\
\text { Publishing House }\end{array}$ & 1956 & \\
\hline & $\begin{array}{l}\text { Moscow: State Literature } \\
\text { Publishing House }\end{array}$ & 1959 & \\
\hline & \multirow{3}{*}{$\begin{array}{l}\text { Saransk: Mordovia } \\
\text { Publishing House }\end{array}$} & 1960 & \\
\hline & & 1961 & \\
\hline & & 1962 & \\
\hline \multirow{3}{*}{$\begin{array}{l}\text { V. E. Lobanok. V } \\
\text { boyah za Rodinu }\end{array}$} & \multirow{3}{*}{ Minsk: Belarus } & 1959 & \\
\hline & & 1961 & \\
\hline & & 1964 & 50000 \\
\hline
\end{tabular}




\begin{tabular}{|c|c|c|c|}
\hline \multirow{3}{*}{$\begin{array}{l}\text { R. N. Machulskiy. } \\
\text { Vechnyi ogon: } \\
\text { partizanskie } \\
\text { zapiski } \\
\end{array}$} & \multirow{3}{*}{ Minsk: Belarus } & 1965 & \\
\hline & & 1969 & \\
\hline & & 1978 & 50000 \\
\hline \multirow{18}{*}{$\begin{array}{l}\text { D. N. Medvedev. } \\
\text { Eto byilo pod } \\
\text { Rovno }\end{array}$} & $\begin{array}{l}\text { Moscow-Leningrad: } \\
\text { State Children Literature } \\
\text { Publishing House }\end{array}$ & 1948 & \\
\hline & Kursk: Kurskaya pravda & 1949 & \\
\hline & $\begin{array}{l}\text { Voronezh: Voronezh Region } \\
\text { Publishing House }\end{array}$ & 1949 & \\
\hline & \multirow{2}{*}{$\begin{array}{l}\text { Tula: Tula Region } \\
\text { Publishing House }\end{array}$} & 1949 & \\
\hline & & 1950 & \\
\hline & $\begin{array}{l}\text { Kuybyshev: Kuybyshev } \\
\text { Region Publishing House }\end{array}$ & 1950 & \\
\hline & Leningrad: Lenizdat & 1950 & \\
\hline & Magadan: Sovetskaya Kolyma & 1951 & \\
\hline & \multirow{5}{*}{$\begin{array}{l}\text { Moscow: State Children } \\
\text { Literature Publishing House }\end{array}$} & 1956 & \\
\hline & & 1957 & \\
\hline & & 1958 & \\
\hline & & 1961 & \\
\hline & & 1962 & \\
\hline & Elista: Kalmizdat & 1968 & \\
\hline & $\begin{array}{l}\text { Tula: Priokskoye } \\
\text { Publishing House }\end{array}$ & 1981 & \\
\hline & $\begin{array}{l}\text { Cheboksary: Chuvash } \\
\text { Publishing House }\end{array}$ & 1982 & \\
\hline & $\begin{array}{l}\text { Rostov-on-Don: Rostov } \\
\text { Publishing House }\end{array}$ & 1985 & \\
\hline & $\begin{array}{l}\text { Kemerovo: Kemerovo } \\
\text { Publishing House }\end{array}$ & 1985 & \\
\hline
\end{tabular}

\begin{tabular}{|c|c|c|c|}
\hline & Moscow: Voenizdat & 1950 & \\
\hline & Moscow: Voenizdat & 1951 & \\
\hline & Kyiv: Goslitizdat Ukrainy & 1951 & \\
\hline & $\begin{array}{l}\text { Sverdlovsk: Sverdlovsk Region } \\
\text { State Publishing House }\end{array}$ & 1952 & \\
\hline & Kazan: Tatgosizdat & 1953 & \\
\hline & Moscow: Voenizdat & 1955 & \\
\hline & Moscow: Sovetsky Pisatel & 1957 & \\
\hline & $\begin{array}{l}\text { Orenburg: Orenburg } \\
\text { Publishing House }\end{array}$ & 1958 & \\
\hline & $\begin{array}{l}\text { Vladimir: Vladimir } \\
\text { Publishing House }\end{array}$ & 1959 & \\
\hline & Moscow: Sovetsky Pisatel & 1959 & \\
\hline & $\begin{array}{l}\text { Barnaul: Altay } \\
\text { Publishing House }\end{array}$ & 1960 & \\
\hline & Kyiv: Radianskiy Pysmennyk & 1963 & \\
\hline & Moscow: Voenizdat & 1964 & \\
\hline & Izhevsk: Udmurtia & 1965 & \\
\hline D. N. Medvedev. & $\begin{array}{l}\text { Barnaul: Altay } \\
\text { Publishing House }\end{array}$ & 1967 & \\
\hline & Moscow: Molodaya Gvardiya & 1968 & \\
\hline & Moscow: Molodaya Gvardiya & 1969 & \\
\hline & $\begin{array}{l}\text { Sverdlovsk: Sredne-Ural } \\
\text { Publishing House }\end{array}$ & 1971 & \\
\hline & Leningrad: Lenizdat & 1972 & \\
\hline & $\begin{array}{l}\text { Grozny: Chechen-Ingush } \\
\text { Publishing House }\end{array}$ & 1975 & \\
\hline & Kyiv: Politizdat Ukrainy & 1978 & \\
\hline & Moscow: Molodaya Gvardiya & 1979 & \\
\hline & Kyiv: Politizdat Ukrainy & 1980 & \\
\hline & $\begin{array}{l}\text { Sverdlovsk: Sredne-Ural } \\
\text { Publishing House }\end{array}$ & 1981 & \\
\hline & Moscow: Izdatelistvo DOSAAF & 1984 & \\
\hline & $\begin{array}{l}\text { Machachkala: Dagestan } \\
\text { Publishing House }\end{array}$ & 1984 & \\
\hline & Chișinău: Literatura Artistike & 1985 & \\
\hline & Moscow: Pravda & 1985 & \\
\hline & $\begin{array}{l}\text { Barnaul: Altay } \\
\text { Publishing House }\end{array}$ & 1985 & \\
\hline
\end{tabular}




\begin{tabular}{|c|c|c|c|}
\hline $\begin{array}{l}\text { N. I. Moskvin. } \\
\text { Partizanskimi } \\
\text { tropami }\end{array}$ & Moscow: Izdatelistvo DOSAAF & 1971 & 100000 \\
\hline \multirow{2}{*}{$\begin{array}{l}\text { T. F. Novak. Parol } \\
\text { znayut nemnogie }\end{array}$} & \multirow{2}{*}{ Moscow: Voenizdat } & 1966 & 100000 \\
\hline & & 1975 & 100000 \\
\hline \multirow{2}{*}{$\begin{array}{l}\text { M. S. Prudnikov. } \\
\text { Neulovimyie }\end{array}$} & Moscow: Voenizdat & 1961 & 115000 \\
\hline & $\begin{array}{l}\text { Yaroslavl: Verkhne-Volga } \\
\text { Publishing House }\end{array}$ & 1964 & \\
\hline $\begin{array}{l}\text { M. G. Salay. } \\
\text { Po znakomyim } \\
\text { dorogam: zapiski } \\
\text { starogo partizana }\end{array}$ & Moscow: Izdatelistvo DOSAAF & 1981 & 100000 \\
\hline $\begin{array}{l}\text { N. I. Schensnovich. } \\
\text { Zapiski aktera } \\
\text { i partizana }\end{array}$ & Minsk: Belarus & 1976 & \\
\hline \multirow{7}{*}{$\begin{array}{l}\text { A. F. Fedorov. } \\
\text { Podpolnyi obkom } \\
\text { deystvuyet }\end{array}$} & $\begin{array}{l}\text { Moscow: Sovetsky } \\
\text { Pisatel (Part 1-2) }\end{array}$ & 1949 & 45000 \\
\hline & $\begin{array}{l}\text { Moscow: Molodaya } \\
\text { Gvardiya (Part 1-2) }\end{array}$ & 1952 & \\
\hline & Moscow: Molodaya Gvardiya & 1954 & \\
\hline & Moscow: Voenizdat & 1955 & \\
\hline & Moscow: Sovetsky Pisatel & 1961 & \\
\hline & Moscow: Sovetsky Pisatel & 1975 & \\
\hline & Chișinău: Literatura Artistike & 1985 & \\
\hline $\begin{array}{l}\text { I. F. Homich. } \\
\text { Myi vernulis }\end{array}$ & Moscow: Voenizdat & 1959 & \\
\hline $\begin{array}{l}\text { A. F. Yudenkov. Za } \\
\text { ognennoy chertoy }\end{array}$ & Moscow: Voenizdat & 1966 & 115000 \\
\hline $\begin{array}{l}\text { V. K. Yakovanko. } \\
\text { Partizanki }\end{array}$ & Moscow: Voenizdat & 1980 & 65000 \\
\hline
\end{tabular}

Денис Шаталов

\section{НЕВИКОРІНЕНА ПАМ'ЯТЬ. ГОЛОКОСТ В РАДЯНСЬКИХ ВІЙСЬКОВИХ МЕМУАРАХ}

Стаття присвячена проблемі презентації теми масового вбивства євреїв у роки Другої світової війни в радянських виданнях. Загальна тенденція замовчування теми Голокосту в радянському публічному дискурсі не підлягає сумніву. Однак картина (не)презентації масового знищення євреїв нацистами в радянській літературі, традиційно зображувана дослідниками, потребує уточнення. Якщо звернутися до масиву радянської літератури про «Велику Вітчизняну війну» (вклю- чаючи і художні твори) ми можемо помітити феномен, презентований у цій статті на прикладі військових мемуарів. Одночасно з офіційним замовчуванням Голокосту в СРСР весь післявоєнний період масово видавалися та перевидавалися десятки мемуарних творів, в яких безпосередньо говорилося про вбивства євреїв нацистами в роки війни.

При цьому часто в мемуарах фронтовиків про вбивства євреїв траплялися лише короткі згадки, без жодних пояснень. Подібний стиль викладу передбачає, що автори розраховували на фонову обізнаність читачів. Детальні описи дискримінації, сегрегації, геттоїзації та вбивств євреїв наявні в публікаціях спогадів колишніх військовополонених та партизанів. Опис нацистського переслідування євреїв, яке було органічною частиною повсякденного життя на окупованій території, інколи займав досить значний обсяг тексту. У певному ідеологічному контексті згадки про вбивства євреїв навіть свідомо інструменталізувалися радянськими мемуаристами, цілеспрямовано використовувались для демонстрації злочинної сутності нацистських колаборантів.

Як можна переконатися на прикладі радянських військових мемуарів, ми не можемо спрощено говорити про однозначну позицію замовчування і повинні осмислити феномен «невикоріненої пам'яті» в напівофіційних текстах. У радянських джерелах, зокрема військових мемуарах, нацистський геноцид євреїв не фігурує як окреме явище, хоча й досить детально описується, але тільки як частина «нового порядку». Ми дійсно стикаємося в радянському публічному просторі 3 замовчуванням Голокосту як окремого феномену, але одночасно, хоча і з обмеженнями, масові вбивства радянських євреїв доволі часто згадувалися у військових мемуарах.

Ключові слова: пам'ять про Голокост, військові мемуари, масові вбивства, радянські євреї, нацистські переслідування.

\section{Bibliography}

Altunin, Aleksandr. Povest' o trevozhnoy molodosti. Moskva: Voennoe izdatel'stvo Ministerstva oborony SSSR, 1981.

Al'tman, Il'ya. «Memorializatsiya Kholokosta v Rossii: istoriya, sovremennost', perspektivy.» Neprikosnovennyy zapas, № 2-3 (40-41) (2005). Accessed December 17, 2018. http://magazines.russ.ru/nz/2005/2/alt28pr.html.

Al'tshuler, Mordekhay. «Deyatel'nost' evreev po uvekovecheniyu pamyati o Kholokoste v Sovetskom Soyuze v epokhu Stalina.» Yad Vashem: Issledovaniya 1, (2009). 
Arad, Yitzhak. «The Holocaust in Soviet Historiography.» In The Historiography of the Holocaust Period. Proceedings of the Fifth Yad Vashem International Historical Conference, 1988, ed. Yisrael Gutman, and Gideon Greif, 187-216. Jerusalem: Yad Vashem, 1988. 1975.

Babadzhanyan, Amazasp. Dorogi pobedy. Moskva: Molodaya gvardiya

Bakradze, David. Karpatskiy reyd. Moskva: DOSAAF, 1968.

Bakradze, David. Krov'yu geroev. Tbilisi: Zarya Vostoka, 1961.

Bankvitser, Akhill. Lyudi nashey divizii. Moskva: Voenizdat, 1962.

Belyavskiy, Vladimir. Strely skrestilis' na Shpree. Moskva: Voenizdat, 1973.

Berezhnoy, Ivan. Dva reyda: vospominaniya partizanskogo komandira 2-e izd., ispr. i dop. Gor'kiy: Volgo-Vyatskoe knizhnoe izdatel'stvo, 1976.

Bondarets, Vladimir. Voennoplennye: zapiski kapitana. Moskva: Molodaya gvardiya, 1960 .

Borzunov, Semen. S perom i avtomatom. Moskva: Voenizdat, 1974. http://militera.lib.ru/memo/russian/borzunov_sm01/index.html.

Boyko, Vasiliy. S dumoy o Rodine. Moskva: Voenizdat, 1982.

Brinskiy, Anton. Po tu storonu fronta. Gor'kiy: Volgo-Vyatskoe knizhnoe izdatel'stvo, 1966. https://royallib.com/book/brinskiy_anton/po_tu_storonu_fronta.html.

Burtsev, Mikhail. Prozrenie. Moskva: Voenizdat, 1981.

Chernyy, Igor'. Dannye dostoverny. Moskva: Voenizdat, 1968.

Chistyakov, Nikolay. Po zakonu i sovesti. Moskva: Voenizdat, 1979.

Clowes, Edith. W. «Constructing the Memory of the Holocaust:

The Ambiguous Treatment of Babii Yar in Soviet Literature.» Partial Answers: Journal of Literature and the History of Ideas 3, no. 2 (2005): 153-182.

Davydov, Il'ya. Yunost' ukhodit v boy. Moskva: Voenizdat, 1973.

Devyataev, Mikhail. Pobeg iz ada. Kazan': Tatarskoe knizhnoe izdatel'stvo, 1988.

Devyataev, Mikhail. Polet $k$ solntsu. Moskva: DOSAAF, 1972.

Dnevnik Anny Frank, predislovie Il'i Erenburga. Moskva: Inostrannaya literatura, 1960.

Dragunskiy, David. Gody v brone. Moskva: Voenizdat, 1973.

Druyan, Ibragim. Klyatvu sderzhali. Minsk: Belarus', 1975. http://militera.lib.ru/memo/russian/druyan/02.html.

Fedorov, Aleksey. Podpol'nyy obkom deystvuet. Moskva: Sovetskiy pisatel', 1949.

Fedorov, Aleksey. Poslednyaya zima. Moskva: Voenizdat, 1985.
Feferman, Kiril. Soviet Jewish Stepchild: The Holocaust in the Soviet Mindset, 1941-1964. Saarbrücken: VDM Verlag, 2009.

«Fond Aleksandra N. Yakovleva. Arkhiv Aleksandra N. Yakovleva.» Accessed December 29, 2018, http://www.alexanderyakovlev.org/fond/issues/ parts/62029/62043.

Gitelman, Zvi. «History, Memory and Politics. The Holocaust in the Soviet Union.» Holocaust and Genocide Studies 5, no. 1 (1990): 23-37.

Gitelman, Zvi. «Politics and Historiography of the Holocaust in the Soviet Union.» In Bitter Legacy: Confronting the Holocaust in the USSR, edited by Zvi Gitelman, 14-42. Bloomington: Indiana University Press, 1997.

Gitelman, Zvi. «Soviet Reactions on the Holocaust.» In The Holocaust in the Soviet Union: Studies and Sources on the Destruction of the Jews in the Nazi-occupied Territories of the USSR, 1941-1945, edited by Lucjan Dobroszycki and Jeffery S. Gurock, 3-27. Routledge, 1994.

Himka, Ivan-Pavlo, i Taras Kurylo. «Yak OUN stavylasya do yevreyiv? Rozdumy nad knyzhkoyu Volodymyra V»yatrovycha.» Ukrayina moderna, № 13 (2): Viyna peremozhtsiv i peremozhenykh (2008): 252-267.

Himka, John-Paul. «Former Ukrainian Policemen in the Ukrainian National Insurgency: Continuing the Holocaust outside German Service.» In Lessons and legacies XII. New Directions in Holocaust Research and Education, edited and with an introduction by Wendy Lower and Lauren Faulkner Rossi, 141-163. Illinois: Northwestern University Press Evanston, 2017.

Himka, John-Paul. «The Lviv Pogrom of 1941: The Germans, Ukrainian Nationalists, and the Carnival Crowd.» Canadian Slavonic Papers, no. 2-3-4 (2011): 209-243.

Hirszowicz, Lukasz. «The Holocaust in the Soviet mirror.» In The Holocaust in the Soviet Union: Studies and Sources on the Destruction of the Jews in the Nazi-occupied Territories of the USSR, 1941-1945, edited by Lucjan Dobroszycki and Jeffery S. Gurock, 29-60. Armonk, NY, 1993.

«Holocaust atlas of Lithuania.» Accessed December 29, 2018, http:// www.holocaustatlas.1t/EN/\#a_atlas/search/ventfr=5000/page/1/ item/69/.

Ignatov, Petr. Zapiski partizana. Moskva: Moskovskiy rabochiy, 1973.

Ignatov, Petr. Zapiski partizana. Kn. 1: V predgor'yakh Kavkaza. Moskva: Molodaya gvardiya, 1944.

Ivanov, Semen. Shtab armeyskiy, shtab frontovoy. Moskva: Voenizdat, 1990.

Kagan, David. Rasskazhi zhivym: dokumental'naya povest'. 2-e izd., dop. Ashkhabad: Turkmenistan, 1986. http://militera.lib.ru/memo/russian/kagan_dz01/text.html\#t1. 
Katyshkin, Ivan. Sluzhili my v shtabe armeyskom. Moskva: Voenizdat, 1979.

Khiterer, Victoria. «Suppressed Memory: Memorialization of the Holocaust in Babi Yar (Kiev).» Accessed December 19, 2018. http://aej.org.ua/ history/1743.html.

Khomich, Ivan. My vernulis'. Moskva: Voenizdat, 1959.

Korey, William. «A monument over Babi Yar?» In The Holocaust in the Soviet Union: Studies and Sources on the Destruction of the Jews in the Nazi-occupied Territories of the USSR, 1941-1945, edited by Lucjan Dobroszycki and Jeffery S. Gurock, 61-74. Routledge, 1994.

Kostyukovskiy, Grigoriy. Napryazhennaya liniya: zapiski voennogo svyazista. Moskva: Voenizdat, 1959. http://militera.lib.ru/memo/russian/ kostyukovsky_ga01/index.html.

Kovanov, Pavel. I slovo - oruzhie. Moskva: Sovetskaya Rossiya, 1982.

Kovpak, Sidor. Ot Putivlya do Karpat. Moskva: Voenizdat, 1945.

Kozlov, Ivan. V krymskom podpol'e: vospominaniya. Moskva: Molodaya gvardiya, 1948.

Kozlov, Vasiliy. Lyudi osobogo sklada. Moskva: Molodaya Gvardiya, 1952.

Kraynyukov, Konstantin. Oruzhie osobogo roda. Moskva: Mysl', 1984.

Krivonogov, Ivan. Rodina zovet: zapiski ofitsera sovetskoy armii. 2-e izd., dop. Gor'kiy: Gor'kovskoe knizhnoe izdatel'stvo, 1963.

Lekht, Naya. Narratives of Return: Babii Iar and Holocaust Literature in the Soviet Union. Diss. for the degree Ph. D. of Slavic Languages and Literatures, University of California, 2013.

Liberman, Mishket. Iz berlinskogo getto v novyy mir. Moskva: Progress, 1979.

Lin'kov, Grigoriy. Voyna v tylu vraga. Saransk: Mordovskoe knizhnoe izdatel'stvo, 1960. http://militera.lib.ru/memo/russian/linkov_gm01/index.html.

Lobanok, Vladimir. V boyakh za Rodinu. Minsk: Belarus', 1964.

Loeffler, James. ««In Memory of Our Murdered (Jewish) Children»: Hearing the Holocaust in Soviet Jewish Culture.» Slavic Review 73, no. 3 (2014): 587-611

Machul'skiy, Roman. Vechnyy ogon': partizanskie zapiski. 3-e izd., dop. i ispr. Minsk: Belarus', 1978.

Mankoff, Jeff. «Babi Yar and the Struggle for Memory.» Ab Imperio, № 2 (2004): 393-415.

Medvedev, Dmitriy. Eto bylo pod Rovno. Moskva: Detskaya literatura, 1968. http://lib.ru/MEMUARY/.../MEDWEDEW/rovno.txt.
Medvedev, Dmitriy. Sil'nye dukhom. Moskva: Pravda, 1985.

Medvedovs'ka, Anna. Holokost v Ukrayini v suspil'niy dumtsi kintsya XX - pochatku XXI st. Dys. ... kand. ist. nauk, Dnipro, 2016.

«Militera: Voennaya literatura.» Accessed December 29, 2018. http:// militera.lib.ru/memo/index.html.

Mitsel', Mikhail. «Zapret na uvekovechenie pamyati kak sposob zamalchivaniya Kholokosta: praktika KPU v otnoshenii Bab'ego Yara.» Golokost i suchasnist': studiï v Ukraïni i sviti, № 1(2) (2007): 9-30.

Moskvin, Nikolay. Partizanskimi tropami. Moskva: DOSAAF, 1971.

Novak, Terentiy. Parol' znayut nemnogie. Moskva: Voenizdat, 1966.

Padzhev, Mikhail. Cherez vsyu voynu. Moskva: Politizdat, 1983.

Pirogov, Andrey. Etogo zabyt' nel'zya. Odessa: Odesskoe knizhnoe izdatel'stvo, 1961.

Pokryshkin, Aleksandr. Kryl'ya istrebitelya. Moskva: Voenizdat, 1944.

Popel', Nikolay. Tanki povernuli na zapad. Moskva-Sankt-Peterburg: Terra Fantastica, 2001.

Popel', Nikolay. Vperedi - Berlin! Moskva: izdatel'stvo DOSAAF, 1970. Poplavskiy, Stanislav. Tovarishchi v bor'be. Moskva: Voenizdat, 1974

Prudnikov, Mikhail. Neulovimye. Moskva: Voenizdat, 1961.

«Rossiyskaya gosudarstvennaya biblioteka.» Accessed January 18, 2019. https://www.rsl.ru/.

Rudling, Per Anders. «The OUN, the UPA and the Holocaust: a Study in the Manufacturing of Historical Myth's.» The Carl Beck Papers in Russian and East European Studies, no. 2107 (2011).

Salay, Mikhayl. Po znakomym dorogam: zapiski starogo partizana. Moskva: DOSAAF, 1981.

Schensnovich, Nikolay. Zapiski aktera i partizana. Minsk: Belarus', 1976. http://militera.lib.ru/memo/russian/schensnovich_ni/01.html.

Shafarenko, Pavel. Na raznykh frontakh: zapiski komandira divizii. Moskva: Voenizdat, 1978.

Shtepenko, Aleksandr. Na dal'nem bombardirovshchike. Moskva: Voenizdat, 1945.

Sokolov, Morits. «Oruzhiem slova.» V Na zemle, v nebesakh i na more. Moskva: Voenizdat, 1979.

Sviridov, Aleksandr. Batal'ony vstupayut v boy. Moskva: Voennoe izdatel'stvo Ministerstva oborony SSSR, 1967.

Teremov, Petr. Pylayushchie berega. Moskva: Voenizdat, 1965.

Toker, Leona. «The Holocaust in Russian Literature.» In Literature of the Holocaust, edited by Alan Rosen, 118-130. Campridge University Press, 2013. 
Tutuchenko, Semen. Lesnye vsadniki. Kiev: Politizdat Ukrainy, 1977.

Vaupshasov, Stanislav. Partizanskaya khronika. Minsk: Belarus', 1971.

Vergasov, Il'ya. Izbrannoe (Kryimskie tetradi). Moskva: Sovetskiy pisa-

tel', 1982.

Vershigora, Petr. «Geroy o geroyakh.» V Sil'nye dukhom, avt. Dmitriy

Medvedev. Kiev: Politizdat Ukrainy, 1978.

Vershigora, Petr. Lyudi s chistoy sovest'yu. Moskva: Voenizdat, 1947.

Vershigora, Petr. Lyudi s chistoy sovest'yu. Kn. 2: Karpatskiy reyd. Mosk-

va: Moskovskiy rabochiy, 1950.

Vershigora, Petr. Reyd na San i Vislu. Moskva: Voenizdat, 1960.

Yakovenko, Vladimir. Partizanki. Moskva: Voenizdat, 1980.

Yudenkov, Andrey. Za ognennoy chertoy. Moskva: Voenizdat, 1966.

Zamertsev, Ivan. Cherez gody i rasstoyaniya. Moskva: Voenizdat, 1965.

Zhivul'skaya, Kristina. Ya perezhila Osventsim. Moskva: Izdatel'stvo inostrannoy literatury, 1960.

Zhukov, Dmitriy, i Ivan Kovtun. 1-ya russkaya brigada SS «Druzhina».

Moskva: Veche, 2010. 